\title{
Guided Bedside Teaching for Early Learners
}

Citation for published version (APA):

Wenrich, M. D. (2018). Guided Bedside Teaching for Early Learners: Benefits and Impact for Students and Clinical Teachers. [Doctoral Thesis, Maastricht University]. Gildeprint Drukkerijen. https://doi.org/10.26481/dis.20180912mw

Document status and date:

Published: 01/01/2018

DOI:

10.26481/dis.20180912mw

Document Version:

Publisher's PDF, also known as Version of record

\section{Please check the document version of this publication:}

- A submitted manuscript is the version of the article upon submission and before peer-review. There can be important differences between the submitted version and the official published version of record.

People interested in the research are advised to contact the author for the final version of the publication, or visit the DOI to the publisher's website.

- The final author version and the galley proof are versions of the publication after peer review.

- The final published version features the final layout of the paper including the volume, issue and page numbers.

Link to publication

\footnotetext{
General rights rights.

- You may freely distribute the URL identifying the publication in the public portal. please follow below link for the End User Agreement:

www.umlib.nl/taverne-license

Take down policy

If you believe that this document breaches copyright please contact us at:

repository@maastrichtuniversity.nl

providing details and we will investigate your claim.
}

Copyright and moral rights for the publications made accessible in the public portal are retained by the authors and/or other copyright owners and it is a condition of accessing publications that users recognise and abide by the legal requirements associated with these

- Users may download and print one copy of any publication from the public portal for the purpose of private study or research.

- You may not further distribute the material or use it for any profit-making activity or commercial gain

If the publication is distributed under the terms of Article $25 \mathrm{fa}$ of the Dutch Copyright Act, indicated by the "Taverne" license above, 
Guided Bedside Teaching for Early Learners:

Benefits and Impact for Students and Clinical Teachers 
The research reported here was carried out at

\section{Maastricht University}

In the School of Heatlh Professions Education

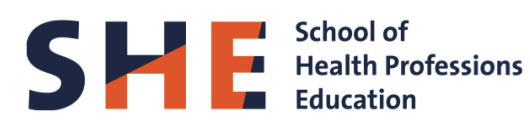

Cover design \& layout: Gildeprint, Enschede Cover photograph courtesy of UW Medicine Printed by: Gildeprint, Enschede ISBN 978-9-4930140-3-9

(C) 2018 Marjorie Dean Wenrich 


\section{Guided Bedside Teaching for Early Learners: Benefits and Impact for Students and Clinical Teachers}

\section{DISSERTATION}

to obtain the degree of Doctor at Maastricht University, on the authority of the Rector Magnificus, Prof. Dr. Rianne M.

Letschert

in accordance with the decision of the Board of Deans, to be defended in public

on Wednesday $12^{\text {th }}$ September 2018, at 16:00 hours

by

Marjorie Dean Wenrich 


\section{Supervisors:}

Prof. dr. A.J.J.A. Scherpbier

Prof. dr. P.G. Ramsey, University of Washington, U.S.A.

\section{Co-Supervisor:}

Dr. H.A.P. Wolfhagen

\section{Assessment Committee:}

Prof. dr. D.H.J.M. Dolmans (chair)

Prof. dr. J.D. Carline, University of Washington, U.S.A.

Prof. dr. A.D.C. Jaarsma, UMC Groningen

Prof. dr. R.P. Koopmans

Prof. dr. W.N.K.A. Van Mook 


\section{Table of Contents}

$\begin{array}{lll}\text { Chapter } 1 & \text { Introduction } & 7\end{array}$

Chapter 2 What are the benefits of early patient contact? A comparison 23 of three preclinical patient contact settings BMC Med Educ 2013;13:80

Chapter 3 Ready or not? Expectations of faculty and medical students for clinical skills preparation for clerkships Med Educ Online 2010, 15: 5295

Chapter 4 Teachers as learners: The effect of bedside teaching on the clinical skills of clinician-teachers Acad Med 2011;86:846-852

Chapter 5 From cheerleader to coach: The developmental progression of bedside teachers in giving feedback to early learners Acad Med 2015;90:S91-S97

Chapter 6 Discussion

Chapter 7 Summary

Samenvatting (Summary in Dutch)

Acknowledgements

About the Author 

Chapter 1

Introduction 
Teaching fundamental clinical skills to medical students is a major and foundational undertaking of medical education. ${ }^{1-2}$ However, since the advent of the Flexner Report in $1910,{ }^{3}$ this important area has traditionally been left to the later years of training after achievement of knowledge of the basic sciences. In recent years, a number of educational approaches have resituated clinical skills training to the preclinical years - the time students spend predominantly in the classroom learning basic sciences. ${ }^{2,4,5}$ Introductory clinical skills training in the pre-clinical years has most frequently involved observation, peer students practicing on one another, use of standardized patients and other approaches that do not utilize real patients or actual clinical settings. ${ }^{1,6}$

Guided bedside teaching is one approach that does locate the early teaching and learning of clinical skills in the actual patient care setting with real patients. Guided bedside teaching has its roots in the broader educational approach known as "learning communities," defined as learning environments created within larger settings where students and faculty members can establish close and sustained professional and personal connections, common goals, and most importantly, learn together and from each other. ${ }^{7}$

The use of learning communities to advance students' clinical skills through the use of teaching in real patient care settings was pioneered in the United States at Harvard Medical School, University of Missouri Kansas City and University of Washington School of Medicine. ${ }^{8-10}$

In this thesis, we focused on clinical skills teaching in a learning community setting prior to the start of clerkships, or "guided bedside teaching," to elucidate its role in advancing students' clinical skills as well as the role of guided bedside teaching in advancing teachers' skills. These studies occurred in one setting, the University of Washington School of Medicine.

In order to be fully effective and accepted, a teaching approach must resonate with, and have unique advantages for, both students and their teachers. Therefore, in this set of studies, we examined: 1) the unique advantages and gaps of guided bedside teaching for preclinical students in addressing their introduction to clinical skills; 2) the unique and comparative advantages and gaps for teachers in advancing their students' clinical skills; and 3) the unique advantages of guided bedside teaching for teachers as teachers - whether guided bedside teaching made them better clinicians and better teachers.

\section{Historical role of clinical exposure in preclinical medical education}

Historically, medical education employed an apprentice model in which students were paired with practicing physicians who taught them through example and instruction in patient care 
settings. The approach was characterized by lack of consistency, structure or standards, with resulting variability in outcomes for student skills development. While apprenticeship most typically occurred in real patient settings, the extent to which apprentices interacted directly with patients under the supervision of their supervisor is unknown. ${ }^{11}$

The Flexner Report substantially modified this approach to one of classroom education focused primarily on basic sciences followed by a sustained period of clinical training. ${ }^{3}$ The two periods were typically separated, with little-to-no exposure to patients and bedside teaching during the first two years followed by little-to-no exposure to basic science instruction during the second two years. This model persisted for 100 years.

While students in some settings had some exposure in the Flexner model to patients and clinical training, there were few standards or expectations that such exposure and training would, or should, occur. ${ }^{12}$ Early training of clinical skills during the pre-clerkship first two years (in the North American four-year model) varied considerably-from structured training outside of the clinical setting, to seeing standardized patients in simulated settings, to shadowing community physicians, to participating in actual clinical work. The amount of such training also varied considerably, from minimal to extensive.

Medical education has again undergone considerable self-examination and change in recent years; one of its most prominent contemporary movements is a call for more clinical exposure for preclinical medical students and better integration of classroom with clinical work. ${ }^{12,13}$ This call is often tied to a call for increasing student exposure to real patients during their formative years. One driver of this is increased attention to patient-centered care. ${ }^{14}$ Another is concern about the relationship of students' classroom theory building to clinical practice and whether theory and principles are consolidated adequately for students without exposure to real practice. ${ }^{15}$ Introducing students to real patients may also ease the transition for students from preclinical to clinical education which, without a gradual and progressive introduction, may be stressful. When medical students enter their clinical years, they report being insufficiently prepared for clinical practice and recommend more real patient contact and a better transition between the preclinical and clinical phase. ${ }^{16}$

Early exposure to patients is associated with: the development of empathy in students; increased confidence; support of cognitive processes by providing both context and a framework through which to understand clinical practice; acquisition of a range of knowledge, especially around the illness experience itself; and development of skills in interviewing and communicating with patients. ${ }^{17}$ In a qualitative study, rationales for early clinical exposure identified by students and faculty included affective broadening, cognitive strengthening and deepening, context, and integration of medical education. ${ }^{18}$ Real patients used as triggers in a problem-based learning (PBL) course were found to complement the 
PBL learning approach by providing: context and relevance to the learning process, complexity and elaborated learning, stimulation of interest, purpose and motivation, focus, empathy, and a patient-centered perspective. ${ }^{19}$

\section{Frequency and varieties of early clinical experience}

Despite calls for increased early clinical exposure, ${ }^{20}$ little is known about the extent of medical students' early exposure to patients at the bedside or in the clinic setting or the extent of students' active involvement in those settings. In a 1993 study assessing educational practices in teaching early medical interviewing and interpersonal skills, most medical education programs incorporated observation and feedback of students' interviews with patients, along with a variety of other teaching techniques, including simulated patients and role playing; considerable variation and intensity of such courses offered in U.S. medical schools was described. ${ }^{21}$

It appears that much clinical exposure prior to clerkships occurs in ambulatory settings, either in clinics or preceptors' private practices. ${ }^{22}$ In a 1995 survey of American medical schools concerning use of community preceptors, nearly all respondents reported using community preceptors and many used them in each year of medical school. ${ }^{23}$ Students interacted with community preceptors most frequently in physicians' private practices. In the systematic review cited above, early patient experiences were often based in community settings (71\%) and, more rarely, in hospital, hospice, or medical school settings (28\%).

A report on the status of Introduction to Medicine courses for preclinical students describes considerable variability in approaches to teaching clinical skills for preclinical medical students in terms of who, where, and how teaching occurs. ${ }^{1}$ For example, the types of teachers involved in teaching the physical examination to preclinical students included clinicianeducators $(57 \%)$, clinician-researchers $(16 \%)$, physicians in private practice $(23 \%)$, nonphysician instructors (17\%), residents/fellows (23\%), and other (34\%).

In our own setting at the University of Washington School of Medicine (UWSOM), many students have historically completed preceptorships with physicians during their first, predominantly classroom-based year. ${ }^{24}$ In addition, in the past, all students completed six patient evaluations over the course of the year with a clinical tutor as part of the second-year Introduction to Clinical Medicine course. These tutors were physicians in a variety of specialties in both academic and community practices, working in both inpatient and outpatient settings. Students had different experiences based on individual tutor variability in approach and interest in teaching - from shadowing to limited direct clinical experience to guided clinic or bedside teaching. 
Partly because of concerns about variability in the experience for different students and increasing difficulty recruiting community physicians to volunteer as their practices became busier, as well as time constraints among academic faculty, the UWSOM moved to a different system of introducing preclinical medical students to clinical medicine, described later.

\section{Preclinical bedside teaching}

Bedside teaching for preclinical students has not been addressed in the literature in a meaningful way, although Ramani has done considerable work recently. ${ }^{25,26}$ What does or might bedside teaching look like at the preclinical level for introducing clinical skills? Other than descriptions of individual programs that utilize preclinical bedside teaching, little is known about the extent to which bedside teaching occurs within preclinical medical education.

The variability of bedside teaching among different clinician-educators described by Nair, ${ }^{27}$ in combination with the novice status of preclinical medical students, means that guidance at the bedside is extremely important — perhaps even more so than during a medical student's clinical years.

The descriptive phrase used in this thesis, "guided bedside teaching," refers to an educational approach and specific techniques developed at the University of Washington School of Medicine (UWSOM) to guide teachers and preclinical students in bedside teaching and learning experiences. At UWSOM, guided bedside teaching occurs predominantly in the inpatient setting for teaching the history and physical examination to second-year students. It relies on comprehensive benchmarks as tools that define and describe the appropriate clinical skills, or competencies, that clinical teachers should teach and that preclinical students should learn, and focuses on basic, standardized teaching and feedback strategies and tools to mentor, monitor, and guide preclinical students at the bedside. These techniques and strategies are discussed in greater detail in the next section.

Several immediate logistical and content problems are associated with inpatient preclinical bedside teaching. Hospitalized patients tend to be the sickest patients and may have obscure or esoteric diseases that are not conducive to teaching basic skills to preclinical students. In addition, preclinical medical students may require additional time with patients to learn the history and physical. In inpatient settings, patients are frequently taken out of their rooms for procedures and tests, creating potential logistical problems for learning. In addition, length of inpatient stay is often very short, resulting in fewer "subjects." Finally, patients may not be willing to participate in bedside teaching due to illness or discomfort with the teaching process. 


\section{Context of the studies}

For the past 15 years, as part of its Colleges program, UWSOM has used the inpatient setting to teach all second-year medical students at the bedside one-half day each week. ${ }^{10}$ This educational innovation resulted from a curriculum review between 1998 and 2001; the primary conclusion of that review was that basic clinical skills development among the School's medical students needed to be strengthened and that medical students within a large, geographically dispersed class need more one-on-one contact with faculty in the preclinical years and beyond. This concern about clinical skill development among medical students is a common theme in medical education. ${ }^{28}$ The Colleges program was initiated to address these needs.

Since 2002, every medical student at the UWSOM is assigned to a College and, within that College, to a faculty mentor. Until 2015, there were six Colleges, each with six faculty mentors who are paid for their work within the Colleges between .25 FTE and .5 FTE, depending on their position as either a regular faculty mentor (.25 FTE) or a College head ( .5 FTE). Each faculty mentor is assigned approximately six medical students per class, for a total of approximately 24 students at any given time across the four years of medical school (i.e., six $1^{\text {st }}$ year students, six $2^{\text {nd }}$ year students, six $3^{\text {rd }}$ year students, and six $4^{\text {th }}$ year students). Since 2015, this model has changed somewhat due to a curriculum reform. The Colleges remain the most integral part of the clinical skills training program but students' also experience an outpatient component with community physicians. The inpatient environment with College groups remains the primary focus of guided, structured clinical skills training.

Since medical students at UWSOM are trained at sites across five different states in first year, relatively little contact occurs in the first year with College mentors other than introductory emails and occasional all-College sessions. In second year, when all students study together in Seattle, the mentor works closely with his/her group of six second-year students as part of the Introduction to Clinical Medicine course. Students spend a half-day each week in a hospital setting with their assigned faculty mentor and group of five other students seeing patients.

Faculty mentors are chosen through a very competitive, school-wide process that identifies and selects possible clinicians/teachers of medical students/role models for students as longitudinal teachers and mentors. Although the majority of College mentors are primarycare physicians (general internal medicine, family medicine, and pediatrics), other specialties and subspecialties of medicine are also represented (surgery, neurology, anesthesiology, psychiatry, obstetrics-gynecology, rehabilitation medicine), and these specialists have had a substantial and important impact on the culture of the College faculty. 
Each week during the academic year, two of the six medical students within a tutorial group are assigned to take a history and perform a physical examination on a patient in an inpatient setting. Prospective patients are identified by "patient interview coordinators," salaried individuals assigned to each of the participating hospitals to find and consent patients to participate in these teaching sessions. The two designated medical students and their faculty mentor each week arrive at the hospital and meet their respective patients. While the two medical students take histories and perform physical examinations, the faculty mentor goes back and forth between the two patient rooms, observing the students and providing feedback and instruction as needed. At the end of two hours, the students leave the patient and organize their notes in preparation for a bedside case presentation.

At that point, the other four students in the mentor's group arrive and after brief discussions, the entire group goes to the bedside, where each of the two medical students gives an oral case presentation (OCP) of their patient. After the OCP, the mentor may ask the other students to give feedback to the student, may provide his/her feedback, and/or may provide teaching points to all the students. Often, the other students have the opportunity to ask the patient questions and to perform relevant and focused physical exam maneuvers on the patient. For example, if a patient has a heart murmur, the mentor may demonstrate for all the students how to identify the murmur and what to listen for, and then give each student the opportunity to listen for the murmur.

This process occurs at both of the bedsides where histories and physical exams were performed by the two students assigned for the week. At the end of the morning, the group reconvenes briefly, if time permits, in a conference room for further discussion before going to classes on campus. Over the subsequent week, the two medical students who examined patients and performed OCPs each complete a write-up of their patient case and submit the write-up to their mentor. The mentor gives detailed written (and sometimes in-person) feedback to the student. In some cases, some mentors ask the students to perform a second, more formal OCP in a conference room the following week, based on verbal and written feedback the students received from the mentor about their write-up.

Throughout the year, each medical student performs a minimum of six complete histories and physical examinations, presents these patients to the mentor and peer group, and prepares a write-up on each patient. In addition, each student has the opportunity to observe his/her peers in the small-group setting at the bedside and to participate in bedside discussion and teaching for an additional 30 patients. 


\section{Benefits of guided bedside teaching for medical students}

Some outcomes of guided bedside teaching for performance in and comfort with starting clerkships have been identified. In a study of student-reported, pre-post study of comfort entering clerkships, students who had undergone guided bedside teaching felt better prepared for, and more comfort with, a number of clinical skills when starting clerkships than students who had not. Overall, the study suggests that early introduction of clinical skills improves medical student comfort at the start of third-year clerkships. ${ }^{29}$

Comparisons of student performance evaluations on the third-year basic clerkships for internal medicine suggest that guided bedside teaching improves students' objectively assessed performance in third year in key areas. ${ }^{30}$ In this pre-post study, students who experienced guided bedside teaching performed better than students who had not experienced guided bedside teaching on nine of 12 clinical skills domains in internal medicine as well as on technical communication skills for three of six clerkships (surgery, internal medicine, pediatrics).

Additional information is needed about the benefits of guided bedside teaching. For example, do the expectations of clerkship directors for beginning medical students align with the skills emphasized in guided bedside teaching? Data suggest that clerkship directors believe students in the United States are not well prepared for clerkships. ${ }^{31}$ In an examination by the Family Medicine Curriculum Resource Project of core competencies needed by medical students by the beginning of the basic clerkship year, student competency deficits were perceived in priority areas. ${ }^{32}$

In guided bedside teaching through the Colleges program and related U.S. programs, the competencies a student should develop in preparation for clerkships are defined as "benchmarks." These benchmarks span a variety of domains, including communication skills, physical exam, clinical reasoning, professionalism, oral case presentations, write-ups, and others. They are used both by the faculty for teaching and by students for ongoing reference, guidance and preparation for objective structured clinical examinations (OSCEs) at the end of their preclinical training.

A comparison of the perspectives of the preclinical teaching faculty with those of clerkship directors on competencies students need for the start of clerkships would provide insight into alignment of expectations. Lack of alignment would suggest guided bedside teaching will not benefit students in preparing them for clerkships or, alternately, may over-prepare them. Alignment would suggest that guided bedside teaching can help reduce the "shock of practice" for students as they begin clerkships and better meet the needs and expectations of clerkship directors and teachers. 
Students who have undergone the Colleges program are also an important voice for defining whether they believe guided bedside teaching prepares them in appropriate areas to an adequate level for clerkships.

An additional area for understanding the benefits and roles of guided bedside to teaching is the ways and extent to which guided bedside teaching differs from other commonly used preclinical modalities for teaching clinical skills. To what extent does guided bedside teaching offer unique skills training not available from other teaching modalities. For example, it is possible that more traditional approaches to early clinical exposure may offer advantages that guided bedside teaching does not offer.

\section{Impact of longitudinal clinical skills teaching on teachers' clinical and teaching skills}

For a teaching modality to be effective and sustainable, it must provide "value added" for teachers. One form of "value added" is compensation as a teacher, either through direct monetary payment or through academic credit toward academic obligations and promotion. Other forms of "value added" are satisfaction with teaching and positive impact on a teacher's own skills.

Experiences that provide "value added" in academic settings are increasingly rare and faculty attrition is increasing in the United States. Multiple competing priorities vie with education for the time and attention of academic teachers, including patient care, the need to generate clinical revenue, research, and administration. Many physicians are at risk of burnout. ${ }^{33}$ In one study, over a fifth of respondents considered leaving academic medicine altogether because of dissatisfaction. ${ }^{34}$ Reasons for dissatisfaction with academic careers include negative perceptions of the academic culture, such as feeling disconnected with others and lacking collegial engagement. ${ }^{35}$ Conversely, sources of workplace satisfaction among faculty include departmental relationships, workplace culture, collaboration opportunities, and appreciation by learners. ${ }^{35}$ Given this, it is important to identify ways in which teaching may increase faculty satisfaction with their careers in order to maximize retention.

Several studies examined the impact for community preceptors of teaching preclinical medical students in ambulatory settings. Teachers reported increased morale, skills improvement, and positive practice infrastructure changes. ${ }^{36-38}$ Skills improvements were attributed to increased reading and reflection, information and challenging questions from students, and increased time with patients. Introduction of a course with early patient contact resulted in general practitioners feeling 'reflected from outside.' Students' questions made teachers observant of their work routines and patient management, elucidated shortcomings and knowledge gaps, and stimulated keeping up-to-date. Such preceptorships frequently occur in outpatient settings. 
A recently described result of intentional groupings of students and faculty for specific purposes like teaching clinical skills has been a positive impact on the faculty themselves. A recent study examined the perceived impact of teaching in learning communities on teachers in five medical schools. ${ }^{39}$ Two major sources of satisfaction were found: campus engagement (feeling happier, improved sense of community, better communication skills, and feeling more productive) and impact on skills (improved clinical skills, being a better doctor). Overall, academic clinical faculty members reported that serving as a mentor in a learning community was a strong source of job satisfaction and may be a tool for retaining clinical faculty members in academic care.

Despite recommendations that teachers acquire bedside teaching skills and reinforce and update their clinical skills, ${ }^{26,40}$ physicians' discomfort with their clinical skills and the progression to diagnosis based on imaging and lab tests may keep physicians from undertaking bedside training. ${ }^{25,41}$ On the other hand, if bedside teaching is shown to improve physicians' clinical skills and/or stimulate their learning, then it has benefits for physicians themselves and for patients through improved quality of care in addition to the benefits it provides for students.

There is little understanding of the impact of inpatient teaching on clinicians' own clinical skills. Identifying the impact may help to advance bedside teaching as a legitimate and necessary teaching modality and may help clinicians understand the personal value of clinical teaching.

A premise of being a teacher is that one's teaching skills will improve over time. Most clinical teachers learn to teach "on the job," often during residency training and with minimal oversight. Despite a number of studies on the attributes of an excellent clinical teacher, there is little in the literature that examines whether or how clinical teachers progress in their teaching skills over time. Examining what clinical teachers initially find challenging and ways in which they change with experience may help clinicians understand their progression as teachers, tailor faculty development, and advance understanding of how teachers move from a "novice" to a more "master" status as teachers. In addition, knowledge of teaching skill development may serve as an incentive to teachers and help them overcome concerns associated with potential inadequate teaching performance.

\section{Research questions and overview of thesis}

In this series of studies, we examined the benefits, limitations and outcomes associated with the educational approach of "guided bedside teaching" for preclinical medical students and for the faculty who teach them. Specific questions associated with our individual studies were: 
1. Does guided bedside teaching offer clinical preparation in areas that students need for the start of clerkships? (Chapter 2)

2. What does guided bedside teaching have in common with other clinical preparation experiences and what does it offer that is unique? (Chapter 3)

3. How successful is guided bedside teaching from the perspectives of medical students? (Chapter 3)

4 How does guided bedside teaching influence teachers' own clinical skills? (Chapters 4)

5. What defines the progression of becoming an accomplished teacher of guided bedside teaching and in what ways do guided bedside teachers progress through ongoing bedside teaching? (Chapter 5)

Chapter 2: While preclinical training has occurred historically in limited and varied fashion, guided bedside teaching is built on the premise that students need more structured and guided preparation in order to succeed as medical students completing clerkships and advanced training. This paper asked the question, What clinical skills are needed for the start of clerkships? The question was addressed from the perspectives of medical students completing clerkships, College mentors serving as guided bedside teachers of preclinical students, and clerkship directors involved in leading clinical clerkships.

Chapter 3: Guided bedside teaching is only one method for providing preclinical exposure to patients and clinical skills training prior to clerkships. Other approaches are the more commonly used preceptorships. This study posed the question of whether and in what ways guided bedside teaching differs from more commonly used approaches and what unique advantages, if any, it offers to students. The study used the perspectives of students themselves who completed three different types of preclinical training with patients.

Chapter 4: In order for guided bedside teaching to succeed as a teaching approach, it must offer benefit to both students and to faculty. Based on a comprehensive set of qualitative analyses, key themes were identified from longitudinal interviews with College faculty, and one resulting theme was isolated for detailed exploration: the impact of guided bedside teaching on teachers' own clinical skills. This paper examined how faculty perceive that sustained bedside teaching with preclinical medical students impacts their own clinical skills.

Chapter 5: While many papers have presented research and/or opinions on what defines a good clinical teacher, few provide insight into the progression of teachers from novices to more experienced teachers. Such information, if available, could help to build faculty development approaches and programs. Interviews from faculty over the first five years of a teaching program provide the opportunity to delve into a question for which there is little existing information: in what specific areas do teachers progress in their teaching skills as 
they learn to become teachers? We isolated one skill theme from the year-long qualitative analysis of College faculty interviews for detailed examination as a lens into skills progression over time: giving feedback to students. We asked the question: How do clinical teachers progress in their skill and approaches to giving feedback to early learners at the bedside over time based on their experience working with students? 


\section{REFERENCES}

1. Omori DM, Wong RY, Antonelli MS, Hemmer PA. Introduction to clinical medicine: A time for consensus and integration. Am J Med 2005; 118: 189-194.

2. Alexander EK. Moving students beyond an organ-based approach when teaching medical interviewing and physical examination skills. Acad Med 2008;83: 906-909

3. Flexner A. Medical Education in the United States and Canada: A Report to the Carnegie Foundation for the Advancement of Teaching. Bulletin No. 4. Boston, Mass: Updyke; 1910.

4. Cooke M, Irby DM, O'Brien BC. Educating Physicians: A Call for Reform of Medical School and Residency. San Francisco: Jossey-Bass; 2010.

5. Chumley H, Olney C. A short transitional course can help students prepare for clinical learning. Fam Med 2005; 37:496-501)

6. La Rochelle J, Durning S, Pangaro L, Artino A, van der Vleuten C, Schuwirth L. Authenticity of instruction and student performance: a prospective randomised trial. Med Educ 2011;45:807-17.

7. Chavis DM, Hogge JH, McMillan DW, Wandersman A. Sense of community through Brunswick's lens: A first look. Journal of Community Psychology 1986;14(1):24

8. https:/hms.harvard.edu/departments/medical-education/student-services/academicsocieties-hms

9. Drees BM, Arnold L, Jonas HS. The University of Missouri-Kansas City School of Medicine: thirty-five years of experience with a nontraditional approach to medical education. Acad Med 2007 Apr;82(4):361-9);

10. Goldstein EA, Maclaren CF, Smith S, Mengert TJ, Maestas RR, Foy HM, Wenrich MD, Ramsey PG. Promoting fundamental clinical skills: A competency-based college approach at the University of Washington. Acad Med 2005; 80(5): 423-433.

11. Kilminster S, Cottrell D, Grant J, Jolly B. AMEE Guide No. 27: Effective educational and clinical supervision. Med Teach. 2007 Feb;29:2-19.

12. Neame RL. The preclinical course of study: Help or hindrance? J Med Educ 1984; 59:900-707.

13. Nutter D and Whitcomb M. The AAMC Project on the Clinical Education of Medical Students. https://www.aamc.org/download/68522/data/clinicalskillsnutter.pdf.

14. Association of American Medical Colleges. Educating Doctors to Provide High Quality Medical Care. A Vision for Medical Education in the United States. Report of the Ad Hoc Committee of Deans. Accessed at: http://www.aamc.org/meded/iime.

15. Diemers AD, Dolmans DH, Van Santen M, Van Luijk SJ, Janssen-Noordman AM, Scherpbier AJ. Students' perceptions of early patient encounters in a PBL curriculum: a first evaluation of the Maastricht experience. Med Teach 2007;29:135-42.

16. Prince KJ, Boshuizen HP, van der Vleuten CP, Scherpbier AJ. Students' opinions about their preparation for clinical practice. Med Educ 2005;39:704-712. 
17. Dornan T, Littlewood S, Margolis SA, Scherpbier A, Spencer J, Ypinazar V. How can experience in clinical and community settings contribute to early medical education? A BEME systematic review. Med Teach 2006;28:3-18.

18. Dornan $\mathrm{T}$ and Bundy $\mathrm{C}$. What can experience add to early medical education? Consensus survey. BMJ 2004;329:834-840.

19. Dammers J, Spencer J, Thomas M. Using real patients in problem-based learning: students' comments on the value of using real, as opposed to paper cases, in a problembased learning module in general practice. Med Educ 2001;35:27-34.

20. Issenberg SB, McGaghie WC. Clinical skills training-practice makes perfect. Med Educ 2002;36:210-211

21. Novack DH, Volk G, Drossman DA, Lipkin M Jr. Medical interviewing and interspersonal skills teaching in U.S. medical schools. Progress, problems, and promise. JAMA 1993;270:1319-1320.

22. O'Brien-Gonzales A, Blavo C, Barley G, Cohn Steinkohl D, Loeser H. What did we learn about early clinical experience? Acad Med 2001;76(4 Suppl):S49-54.

23. Fields SA, Usatine R, Stearns JA, Toffler WL, Vinson DC. The use and compensation of community preceptors in U.S. medical schools. Acad Med 1998;73:95-97.

24. Johnson AK, Scott CS.I Relationship between early clinical exposure and first-year students' attitudes toward medical education. Acad Med 1998 Apr;73(4):430-2.

25. Ramani S. Twelve tips to improve bedside teaching. Med Teach 2003;25:112-5.

26. Ramani S, Orlander JD, Strunin L, Barber TW. Whither bedside teaching? A focus group study of clinical teachers. Acad Med 2003 Apr;78(4):384-90.

27. Nair BR, Couglan JL, Hensley MJ. Student and patient perspectives on bedside teaching. Med Educ 1997;31:341-346.

28. Holmboe ES. Faculty and the observation of trainees' clinical skills: problems and opportunities. Acad Med 2004; 79:16-22.

29. Whipple ME, Barlow CB, Smith S, Goldstein EA. Early introduction of clinical skills improves medical student comfort at the start of clerkships. Acad Med 2006; 81 (10 Suppl): 540-543.

30. Jackson MB Keen M, Wenrich MD, Schaad DC, Robins L, Goldstein EA. Impact of a pre-clinical clinical skills curriculum on student performance in third-year clerkships. Arch Int Med 2009:24:929-933.

31. Windish DM, Paulman PM, Goroll AH, Bass EH. Do clerkship directors think medical students are prepared for the clerkship years? Acad Med 2004;79:56-61.

32. Matson CC, Stearns JA, Defer T, Greenberg L, Ullian JA. Prerequisite competencies for third-year clerkship: an interdisciplinary approach. Fam Med 2007;39:38-42.

33. Shanafelt TD, Boone S, Tan L, Dyrbye LN, Sotile W, Satele D, West CP, Sloan J, Oreskovich MR.. Burnout and satisfaction with work-life balance among US physicians relative to the general US population. Arch Intern Med 2012;172:1377-85. 
34. Pololi LH, Krupat E, Civian JT, Ash AS, Brennan RT. Why are a quarter of faculty considering leaving academic medicine? A study of their perceptions of institutional culture and intentions to leave at 26 representative U.S. medical schools. Acad Med. 2012;87:859-69.

35. Bunton SA, Corrice AM, Pollart SM, Novielli KD, Williams VN, Morrison LA, Mylona E, Fox S. Predictors of workplace satisfaction for U.S. medical school faculty in an era of change and challenge. Acad Med 2012;87:574-81

36. Ingham G, Fry J, O’Meara P, Tourle V. Why and how to general practitioners teach? An exploration of the motivations and experiences of rural Australian general practitioner supervisors. BMC Medical Education 2015; 15:190.

37. Hartley S, Macfarlane F, Gantley M, Murray E. Influence on general practitioners of teaching undergraduates: Qualitative study of London general practitioner teachers. BMJ1999;319:1168-1171.

38. Haffling AC, Håkansson A, Hagander B. Early patient contact in primary care: A new challenge. Med Educ 2001;35:901-908.

39. Wagner JM, Fleming AE, Moynahan KF, Keeley MG, Bernstein IH, Shochet RB. Benefits to faculty involved in medical school learning communities. Med Teach 2015;37:476-81.

40. Carlos WG, Kritek PA, Clay AS, Luks AM, Thomson CC. Teaching at the bedside: Maximal impact in minimal time. Ann Am Thorac Soc 2016 Apr;13(4):545-8.

41. Ramani S. Twelve tips for excellent physical examination teaching. Med Teach 2008;30:851-856. 



\section{Chapter 2}

What are the benefits of early patient contact? - a comparison of three preclinical patient contact settings

MD Wenrich, MB Jackson, I Wolfhagen,

PG Ramsey, AJ Scherpbier

Published in BMC Med Educ 2013;13:80 


\section{ABSTRACT}

\section{Background}

Despite increasing attention to providing preclinical medical students with early patient experiences, little is known about associated outcomes for students. The authors compared three early patient experiences at a large American medical school where all preclinical students complete preceptorships and weekly bedside clinical-skills training and about half complete clinical, community-based summer immersion experiences. The authors asked, what are the relative outcomes and important educational components for students?

\section{Methods}

Medical students completed surveys at end of second year 2009-2011. In 2009, students compared/contrasted two of three approaches; responses framed later survey questions. In 2010 and 2011, students rated all three experiences in relevant areas (e.g., developing comfort in clinical setting). Investigators performed qualitative and quantitative analyses.

\section{Results}

Students rated bedside training more highly for developing comfort with clinical settings, one-on-one clinical-skills training, feedback, active clinical experience, quality of clinical training, and learning to be part of a team. They rated community clinical immersion and preceptorships more highly for understanding the life/practice of a physician and career/specialty decisions.

\section{Conclusions}

Preclinical students received different benefits from the different experiences. Medical schools should define objectives of early clinical experiences and offer options accordingly. A combination of experiences may help students achieve clinical and team comfort, clinical skills, an understanding of physicians' lives/practices, and broad exposure for career decisions. 


\section{BACKGROUND}

The medical education community has increasingly emphasized the value of early patient contact experiences for preclinical medical students. In the influential volume Educating Physicians from the Carnegie Foundation, the authors called for early clinical immersion to help integrate skills and knowledge in preparation for practice. ${ }^{1}$

Dornan defined early clinical experience as pre-clerkship experiences with authentic patient contact in a clinical context that enhances learning. ${ }^{2}$ These experiences frequently take the form of community-based preceptorships. Objectives may include: developing comfort with patients; basic clinical-skills training; promoting career interest in primary care and specialty understanding; encouraging active learning in preclinical settings; and reducing the "shock of practice" that some students experience as they enter clerkships. ${ }^{3,4}$ Data suggest that early clinical exposure can make basic science curricula more relevant ${ }^{5}$ and help prepare students for clerkships. ${ }^{6}$

Dornan's review suggests that early experiences help students socialize to medicine, strengthen learning and skills acquisition, and make learning more relevant. ${ }^{2}$ Yardley's follow-up study suggests that early experiences help students understand and align with patient and community perspectives. ${ }^{7}$

Theory supports use of early patient experiences. ${ }^{89}$ Concrete experience is essential to learning; active experience, as opposed to observation, provides the greatest impact on learning and seeing patients independently may be the optimal setting for achieving positive learning outcomes. ${ }^{9}$ Important in early patient encounters, Ottenheijm and colleagues argue, is continuous supervision, reflection between student and supervisor, and timely feedback. Early clinical experiences may provide legitimate peripheral participation, gradually drawing students into the workplace. ${ }^{10}$

Early clinical experiences may be associated with better academic performance, ${ }^{11}$ career interest in relevant specialties 5 , improvement in the "shock of practice" as students transition into clinical settings, ${ }^{3}$ and greater comfort entering clerkships. ${ }^{12}$ While a recent study showed no differences between pre-clerkship teaching formats for outcomes in clerkships, none of the teaching formats involved direct contact or involvement with real patients. ${ }^{13}$

Yardley noted that two specific questions have not yet been fully answered: 'How and why do particular early experience interventions lead to specific learning outcomes?' and 'What is essential to make early authentic experience a more effective process?'7 Hopavian and colleagues have noted the lack of national guidance in the United Kingdom that supports a 
minimum quantity of patient contact or specific educational purpose in the early years of U.K. basic medical training. ${ }^{14}$ As medical schools move toward competency-based approaches $^{15}$ and other curricular models that attempt to identify and shape student experience and to define what students obtain from each stage of learning, ${ }^{16}$ it is important to understand what competencies students receive from preclinical patient experiences. This can help assess the relationship between curricular objectives and outcomes and will help guide choices for early clinical programs.

We used a mixed-method, iterative approach to compare three types of preclinical patient contact at a medical school where many students complete all three, and all complete at least two of the three. In assessing and comparing students' experiences within these approaches, we asked, what are the relative benefits for students from different types of early patient contact and what are the important educational components for students from each?

\section{METHODS}

First-year medical students at the University of Washington School of Medicine must complete at least one community preceptorship and are encouraged to complete one or more in second year as well. These preceptorships consist of half-day, unstructured experiences in the offices of community physicians; students can select the specialty of the preceptor with whom they work. The preceptorships are arranged and monitored by individual departments. Students' involvement varies considerably, from shadowing the preceptor to active participation (i.e., taking history, performing physical exam under supervision).

Approximately half of medical students complete an optional four-week full-time community immersion in a rural or urban underserved setting called the Rural/Underserved Opportunities Program (R/UOP) between their first and second years. ${ }^{17}$ In R/UOP, students live in the community of their preceptor (typically a rural community) and get to know the community in addition to the preceptor's practice; the immersion experience lacks formal structure in terms of clinical objectives and expected clinical outcomes. As with preceptorships, the level of student involvement varies considerably, depending on the preferences of the preceptor. Students may shadow the R/UOP preceptor (often including other preceptors in the community) or may be more actively involved in simple tasks such as history-taking and learning physical exam under supervision. Preceptors receive extensive orientation materials, including how to introduce students into one's practice, administrative issues such as liability, information about students' coursework to date, etc. A standard evaluation form is used to assess student performance on characteristics such as student's practice management skills, clinical skills and attitude. 
Finally, throughout second year, medical students spend one-half day weekly with a dedicated faculty mentor and a small group of peers learning clinical skills at the bedside through the Colleges program, a structured curricular program with an established group of faculty mentors. ${ }^{18}$ Each week, two of the six students in each small group are assigned to independently complete a full history and physical on a hospitalized patient. Patients seen by the students are not from the College mentors' practices; rather, they are patients who are selected on the morning of the tutorial at local medical centers by patient interview coordinators who are trained to identify and approach patients about voluntary participation in this educational activity.

The students' College mentor moves back and forth between the two students as they work with patients, observing, taking notes and offering suggestions. The six students then convene with the mentor for student oral case presentations at the bedside. Students who are observing that morning then ask follow-up questions of the patient about their past medical history and presenting concern; the College mentor guides the bedside discussion and often demonstrates interview and physical exam techniques. Patients are invited to participate actively in these bedside discussions. After the session, each interviewing student completes a full write-up of their patient case and submits it to the College mentor for review. Over the course of a year, each student performs a full history and physical, oral case presentation, and write-up on six patients (and observes an additional 30 bedside presentations by their peers). College mentors give explicit constructive feedback during College mornings, as well as in several one-onone meetings with students throughout the year.

The stated goals of first- and second-year preceptorships are to: provide early patient contact that allows students to become more comfortable in patient encounters; provide opportunities to observe and practice physician-patient communication; and provide student awareness about the practice of a particular specialty. The stated goals of R/UOP are to: provide students with early exposure to the challenges and rewards of primary-care medicine in a rural or urban underserved setting; promote positive attitudes toward rural and urban underserved community medicine; and learn how community healthcare systems function. The stated goals of the Colleges are to provide systematic clinical-skills training and early patient contact in a consistent pre-clinical experience.

In the past, required first-year and optional first- and second-year community preceptorships were the primary venue for early patient exposure and pre-clerkship clinical-skills training (apprenticeship model), augmented by classroom and standardized-patient training; there was minimal control over preceptorship content in multiple settings. The Colleges program was developed to build basic clinical skills in the context of real patients, provide exposure to patients, and help students develop a long-term mentoring relationship with a faculty member (experience-based learning). 
Having three different early patient experiences in the same medical school permits assessment of their respective roles for students. We assessed domains common to the three settings and asked whether the three types of early patient contact achieve similar or unique outcomes across those domains from students' perspectives. If there are common experiences in the different settings, they may be redundant or duplicative; however, if the experiences have unique aspects of complementary value to students, encouraging multiple early patient care experiences may be useful for other medical schools insofar as the experiences align with curricular goals. In order to focus on competencies, we excluded areas such as motivation, confidence building, and other affective domains that have been assessed elsewhere and that are less likely to fall within curricular objectives. ${ }^{16}$

\section{Instruments}

Data were collected across three consecutive years from students during spring of their second year. Areas examined were common to all three settings and relevant to students' future needs. The process of item development was iterative; results from each year informed questions posed in the subsequent year. The data sets were:

1. 2009 survey: We asked students to compare and contrast their preceptorship experiences with training experience in the Colleges program. Students were specifically asked: Please comment on similarities and differences between clinical-skills training during preceptorships and through the Colleges in second year. The response option was openended, with no prompts. Students were asked to identify preceptorships they completed and whether they completed R/UOP.

2. 2010 and 2011 surveys: Based on the domains identified in the 2009 survey and programmatic objectives for early patient experiences, we asked students in 2010 to rate their early patient experiences $\left(1^{\text {st }}\right.$ year preceptorships, $2^{\text {nd }}$ year preceptorships, R/UOP, and Colleges) on the following using a Likert scale ( $1=$ not at all useful to $5=$ extremely useful): developing comfort in clinical settings, receiving one-on-one clinical-skills training, receiving feedback on clinical performance, and understanding the daily life of a physician. Students were also asked to rate how passive or active their clinical experience was in each setting and the overall quality of their clinical training in these settings. Students were asked to identify preceptorships completed and whether they completed R/UOP. Because the Colleges program was relatively new at the time and being closely evaluated, we asked what single aspect of the Colleges is most important to them, using an open-ended format, to ascertain if other aspects of the College experience not asked about were important for students. In 2011, we repeated a portion of the 2010 survey but added two additional questions to address areas missing from the 2009 survey 
and of likely importance to the student experience based on the literature and student comparisons of preceptorships and the Colleges. Due to survey space limitations, we deleted questions asked in 2010 to allow the two new questions in 2011. The new dimensions were: learning to be part of a team and making career/specialty decisions. The deleted dimensions were receiving feedback, passive/active experience and overall quality of clinical training (the latter was seen as comparable to one-on-one clinical skills training). Because no statistically significant differences were found in ratings of firstand second-year preceptorships in 2010, we combined them into a single category of preceptorships in 2011. Students were asked to list preceptorships completed. In 2011, the same Likert scale was used as in 2010.

\section{Participants and data collection}

Second-year medical students completed 2009 and 2010 surveys in debriefing sessions at the completion of a required objective structured clinical examination (OSCE) held each May. In 2011, students completed the survey in June as part of an end-of-year program evaluation survey. Participation was voluntary.

\section{Analyses}

Open-ended comments about similarities and differences between preceptorships and Colleges were analyzed using open coding. Comments were reviewed and grouped into themes, first by one investigator (MDW) and then independently by a second investigator (MBJ) to validate themes in initial coding. Codes were entered into a qualitative data entry program, Atlas Ti, and reviewed for agreement and to resolve disagreements between the two investigators' coding. Disagreements were discussed and consensus developed. For the openended question asked in 2010, "What single aspect of the Colleges is most important to you," a single investigator (MDW) reviewed and assigned codes to responses. For the 2010 and 2011 survey results, data were entered into SPSS and descriptive statistics were prepared. Analysis of variance was performed to compare responses, with type of experience (preceptorship, R/UOP, and College group) as independent variables. Post-hoc comparisons were completed using Fisher's Least Significant Difference Test. The alpha was set at .05.

\section{Ethical approval}

This study received ethical review by the University of Washington Human Subjects Division and received approval as an exempt study. 


\section{RESULTS}

Response rates for the three surveys were:

2009: 191 surveys completed out of 191 OSCE examinees: $100 \%$

2010: 218 surveys completed out of 218 OSCE examinees: $100 \%$

2011: 145 surveys completed out of 200 medical students: $73 \%$

\section{Contrasts between preceptorships and College experience}

Table 1 shows the most frequent contrasts/comparison in themes identified from open-ended comments in 2009 by students concerning clinical training in community preceptorships compared with the Colleges. 
Table 1: 2009 comparisons of the College experience with community preceptorships identified by second-year medical students.

\begin{tabular}{lll}
\hline $\begin{array}{l}\text { Comment } \\
\text { category }\end{array}$ & $\begin{array}{l}\text { Dominant } \\
\text { comparison }\end{array}$ & Sample quotes \\
\hline
\end{tabular}

Passive versus Colleges active, “Preceptorships haven't been much more than active learning hands-on shadowing...College actually provides the opportunity Preceptorships to DO what I'm learning." shadowing

Comprehensive Colleges versus focused comprehensive

"I learned a lot more specialized information in my preceptorship versus general information in [Colleges].

Preceptorships Preceptorships offer a better intro into the clinical world specialized, focused and short focused histories and physicals. Both were beneficial."

Structured Colleges 'College is very 'ideal'-follows versus structured, guidelines/benchmarks...Preceptorships very quick and unstructured rigorous, formal

Preceptorships "Colleges are more formalized to cover all bases. In unstructured, preceptorships, we get lots of exposure to bread \& spontaneous, butter, but less variety. I think they are relaxed complementary."

Specific skills Colleges in "Preceptorship was good for learning the mechanics areas physical exam \& and how you treat. Colleges good for interviewing, PE, clinical reasoning OCP, and clinical reasoning."

Preceptorships in techniques, procedures, treatment

Real life versus Colleges academic theoretical, "Much more opportunity to practice and receive academic feedback through Colleges. Much more opportunity to Preceptorships learn specifics of clinical care, realities of practice and real life exposure to potential career options through preceptorships." 
In response to the open-ended question asked in 2010, "What single aspect of the Colleges is most important to you," the three most frequent responses focused on: 1) patient contact (45 comments); 2) mentor relationship with a faculty member (33 comments); and 3) working in a team/small group setting (33 comments), including development of camaraderie. The second tier of comments focused on skill development: specific skill areas (29 comments), one-on-one teaching from a mentor (24 comments), bedside learning (19 comments) and receiving feedback (19 comments).

\section{Assessments of learning experiences in specific domains}

Results from 2010 and 2011 surveys are shown in Figures 1 and 2. In analysis of variance, statistically significant differences were found for all six domains in 2010 and four of five domains in 2011.

Figure 1: 2010 comparison of second-year student ratings of different early patient contact experiences $(n=218)$.

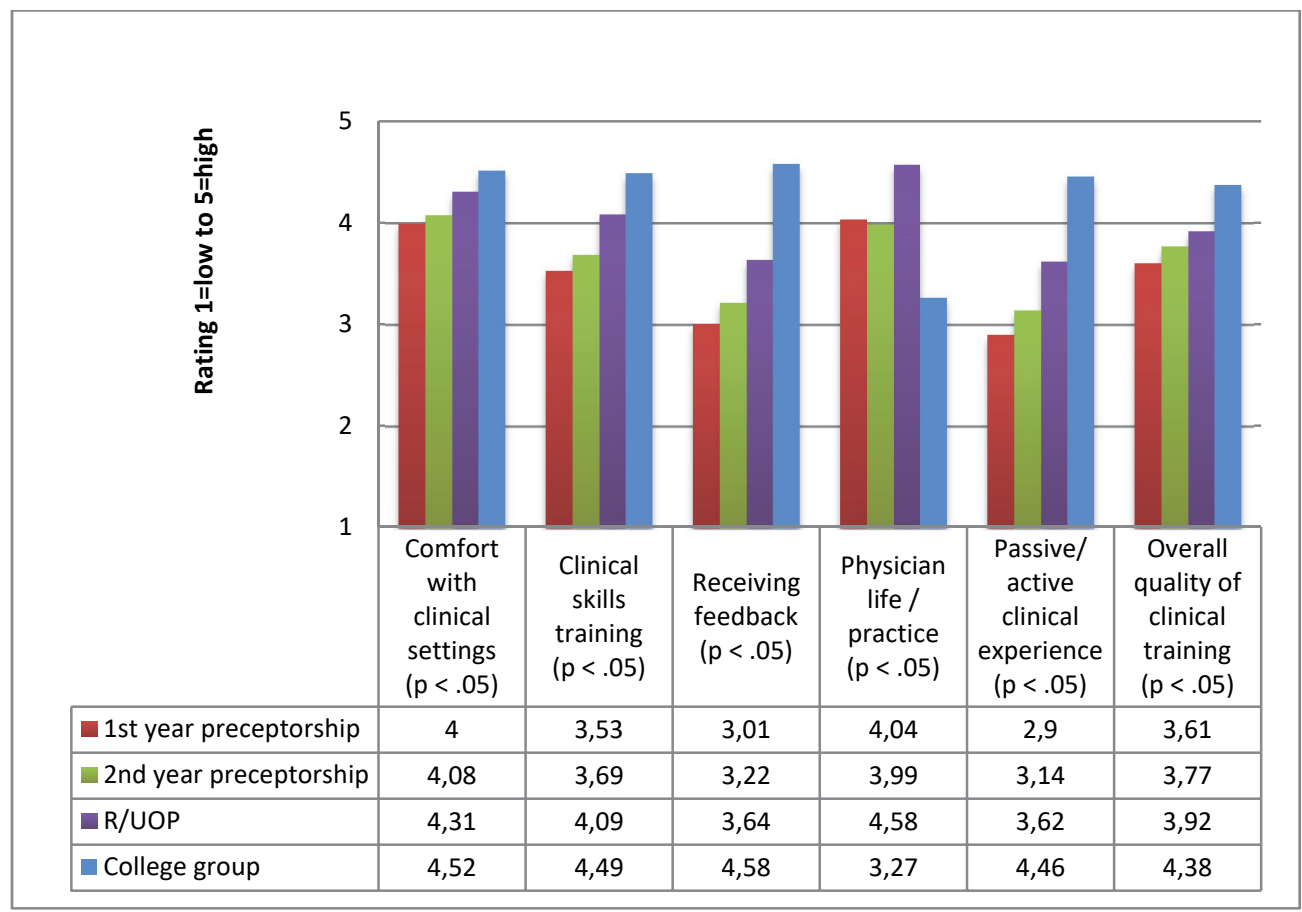


Figure 2: 2011 comparison of second-year student ratings of different early patient contact experiences $(n=145)$.

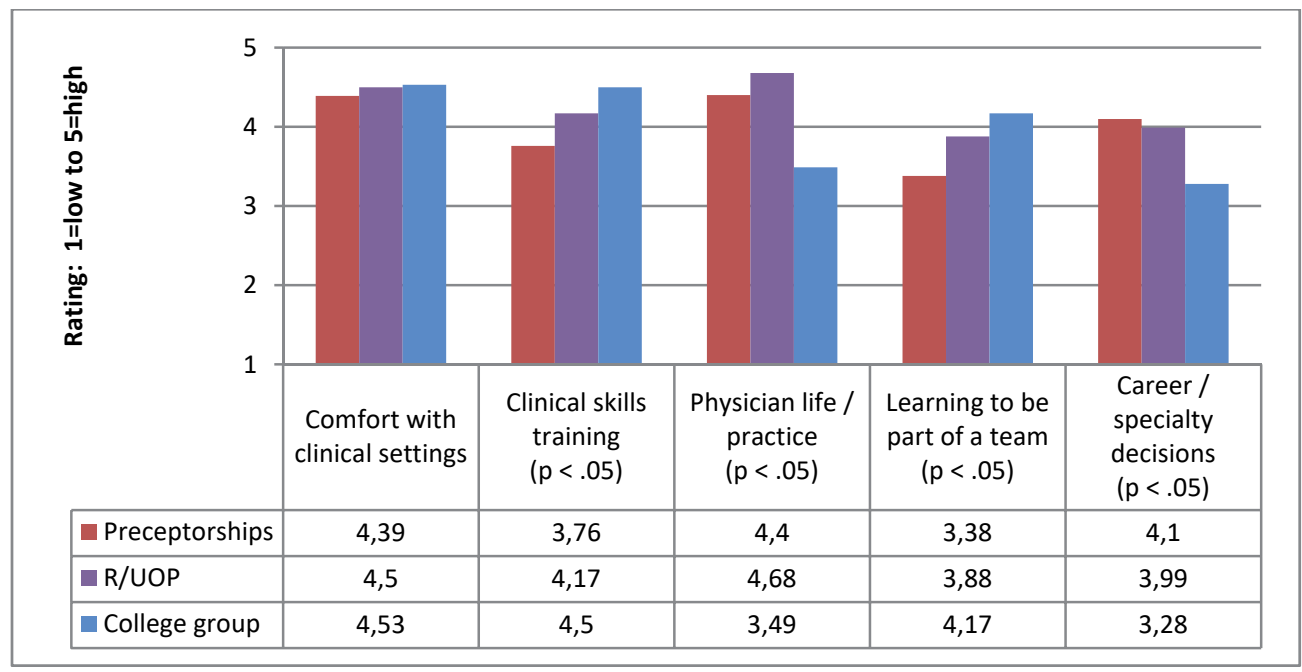

For analyses related to clinical skills training, students rated the Colleges experience significantly higher than R/UOP and preceptorships for one-on-one clinical-skills development in 2010 and in 2011. They also rated R/UOP significantly higher than preceptorships in both years. For receiving feedback and overall quality of clinical training (asked in 2010), the same pattern was seen: students rated the Colleges significantly higher than both R/UOP and preceptorships and rated R/UOP significantly higher than first-year preceptorships.

For analyses related to developing comfort with clinical settings, students rated the Colleges significantly higher than R/UOP and preceptorships in 2010 and also rated R/UOP significantly higher than preceptorships. However, in contrast to 2010, no significant differences were found for the category of developing comfort with clinical settings in 2011 . For learning to be part of a team, asked in 2011, students rated the Colleges and R/UOP significantly higher than preceptorships. For having an active compared with passive learning experience asked in 2010, students rated the Colleges significantly higher than both R/UOP and preceptorships and rated R/UOP significantly higher than preceptorships. 
For analyses related to considering and examining career or physician practice characteristics, a different pattern was seen. For understanding the life of the physician/what practice is like, students rated R/UOP and preceptorships significantly higher than the Colleges in 2010 and 2011, and rated R/UOP significantly higher than preceptorships in both years. For career/specialty decisions asked in 2011, students rated R/UOP and preceptorships significantly higher than the Colleges.

\section{DISCUSSION}

As medical education moves to new curricular models, including competency-based education with defined objectives, benchmarks and outcomes and more standardized approaches it is important to understand and set objectives for each phase of education. ${ }^{19,20}$ While earlier work has defined existing types of early patient experience during the preclinical phase, ${ }^{2}$ there has been limited attention to the relative values of these experiences for medical students or to the objectives, competencies and outcomes associated with early patient experiences. Understanding the benefits of each will help shape the best experiences in accordance with a curriculum's objectives.

In a medical school with three different types of early patient contact, we compared the experiences for broad outcome areas: developing comfort in clinical settings, clinical-skills training and receiving feedback, getting to know specialties and considering potential careers, and team acculturation and active engagement. We found that students received different benefits from the different types of experiences. No single experience offered all these potential benefits.

The Colleges small-group experience, under the supervision of a faculty mentor and within a small group of peers, provided benefits compared with community-based preceptorships in clinical-skills training, active learning and team acculturation. Students rated the Colleges experience significantly higher in quality and extent of skills training, receiving feedback, and active learning than the other types of early patient experience. The R/UOP immersion experience, although rated significantly lower than the Colleges in most clinical-skills areas, was rated significantly higher than limited community preceptorships in most categories across years. The Colleges engendered the greatest development of comfort in clinical settings in 2010 over all other settings, but there were no differences in 2011 . The high ratings for all three settings suggest that all of the experiences advance comfort in clinical settings. In contrast, for understanding the life of a physician and what practice is like, both types of community preceptorships were rated significantly higher than the Colleges. R/UOP, in which students live in a community and are intensely involved for a month, was rated highest 
for understanding the life of a physician. Similarly, for career/specialty decisions, both $\mathrm{R} / \mathrm{UOP}$ and preceptors showed clear advantages over the Colleges.

All three types of early patient experience appear to achieve their stated goals. Preceptorships do not appear to promote student comfort with patients to the same extent as R/UOP and the Colleges; this may be due to considerable shadowing during preceptorships rather than active engagement, as identified in the 2009 comparisons by students of preceptorships with Colleges. Students were, however, able to receive exposure to specialty and career roles through preceptorships, in which they joined practice types of their choice.

The R/UOP experience, in which students live and work in a community, appeared to have the strongest impact on understanding practice and the life of the physician. It also appeared to provide active learning with a focus on clinical skills and feedback. The concentrated dayto-day contact with a physician preceptor that characterizes R/UOP for a full month may provide greater familiarity and comfort between the student and preceptor, leading to more intensive focus on and involvement in teaching and learning.

These data provide guidance for medical schools as they look to desired and expected outcomes associated with early patient experiences. It is important to note that there was some variability in students' responses to community preceptorships; some students described very active, hands-on community preceptorships. However, the more common experience was shadowing with little active involvement. R/UOP also provided variable experiences, from shadowing to very active involvement, but there was more evidence of active learning, as indicated by significantly higher ratings in relevant categories than for preceptorships.

Only the Colleges had a structured, systematic approach to ensuring student responsibility at the bedside. Yardley and colleagues have made the important observation that learners actively influence learning environments just as learning environment actively influence learning; thus, experiential learning is located within bi-directional interactions. ${ }^{8}$ In the Colleges model, students are active participants with defined roles that are preliminary to, yet moving toward, active roles as meaningful clinical providers. The R/UOP model has less structure than the Colleges but more immersion than preceptorships as a result of living in and being a guest member of the preceptor's community. In both settings, students are able to influence their environment; in contrast, preceptorships appear to provide primarily passive shadowing without the ability of the student to influence his/her environment or develop meaningful relationships within that environment. However, students receive a "snapshot" of active physician life that can help with future decisions and understanding the roles of physicians. 
As medical schools assess early patient contact, we recommend the following: Clinical-skills training may be maximized by structured experiences with faculty mentors dedicated to longitudinal teaching at the bedside in which students are assigned to specific roles with patients, including conduct of history, physical examination, preliminary differential diagnosis, oral case presentation, and write-ups. This appears to provide contact with patients, active learning, skills training, and acculturation to teams. For orienting students to physician life and specialty choices, preceptorships and R/UOP-type experiences provide insights into the life of a physician and potential career preferences. The R/UOP experience appears to be particularly valuable for understanding the life of a physician, as students see physicians in their community during and after hours, and develop a relationship with a preceptor that permits sustained learning, understanding and acculturation.

This study has several limitations. The study was conducted at a single large medical school and therefore the findings may not be generalizable to other medical schools. However, few medical schools provide multiple types of early patient experiences and this comparison, even if at a single site, provides valuable information. We were unable to assess whether students used early patient experiences to integrate knowledge and skills, as called for by the Carnegie report. ${ }^{1}$ The most structured experience, the Colleges, is not formally tied to the classroom curriculum, although there is sometimes overlap. The other early patient contact experiences are unrelated to curriculum content. We also looked at a limited set of outcomes and did not assess potential affective outcomes. We wanted to assess areas common to the three settings that might be tied to concrete curricular goals.

\section{CONCLUSIONS}

Different types and formats of early patient experiences may provide unique learning outcomes and acculturation for preclinical medical students. In developing medical school curricula, educators may benefit from assessing the objectives of offering patient experiences for preclinical students-whether clinical-skills development, acculturation to clinical settings, career exposure, or other-and plan patient experience formats accordingly. Careful attention might focus on the extent to which an active experience is desired for preclinical students; if active involvement is favored, more structured experiences like the Colleges and/or more intensive experiences like R/UOP may succeed better. Our data suggest that offering multiple types of early patient experiences may provide students with a broader set of concrete outcomes than a single type of early patient experience. 


\section{REFERENCES}

1. Cooke M, Irby DM, O’Brien BC: Educating Physicians: A Call for Reform of Medical Schools and Residency. San Francisco: Jossey-Bass; 2010.

2. Dornan T, Littlewood S, Margolis SA, Scherpbier A, Spencer J, Ypinazar V: How can experience in clinical and community settings contribute to early medical education? A BEME systematic review. Med Teach 2006, 28:3-18.

3. Godefrooij MB, Diemers AD, Scherpbier AJ: Students' perceptions about the transition to the clinical phase of a medical curriculum with preclinical patient contacts; a focus group study. BMC Med Educ 2010, 10:28.

4. Diemers AD, Dolmans DH, Verwijnen MG, Heineman E, Scherpbier AJ: Students' opinions about the effects of preclinical patient contacts on their learning. Adv Health Sci Educ Theory Prac 2008, 13:633-647.

5. Elnicki DM, Halbritter KA, Antonelli MA, Linger B: Educational and career outcomes of an internal medicine preceptorship for first-year medical students. $J$ Gen Intern Med 1999, 13:341-346.

6. Windish DM, Paulman PM, Goroll AH, Bass EB: Do clerkship directors think medical students are prepared for the clerkship years? Acad Med 2004, 79:56-61.

7. Yardley S, Littlewood S, Margolis SA, Scherpbier A, Spencer J, Ypinazar V, Dornan T: What has changed in the evidence for early experience? Update of a BEME systematic review. Med Teach 2010, 32:740-746.

8. Yardley S, Teunissen PW, Dornan T: Experiential learning: transforming theory into practice. Med Teach 2012, 34:161-164.

9. Ottenheijm RP, Zwietering PJ, Scherpbier AJ, Metsemakers JF: Early student-patient contacts in general practice: an approach based on educational principles. Med Teach 2008, 30:802-808.

10. Lave J, Wenger E: Situated Learning: Legitimate Peripheral Participation. Cambridge: Cambridge University Press; 1991.

11. Jackson MB, Keen M, Wenrich MD, Schaad DC, Robins L, Goldstein EA: Impact of a pre-clinical clinical skills curriculum on student performance in third-year clerkships. $J$ Gen Intern Med 2009, 24:929-933.

12. Whipple ME, Barlow CB, Smith S, Goldstein EA: Early introduction of clinical skills improves medical student comfort at the start of third-year clerkships. Acad Med 2006, 81(10 suppl):S40-S43.

13. Durning SJ, LaRochelle J, Pangaro L, Artino AR Jr, Boulet J, van der Vleuten C, Hemmer P, Denton D, Schuwirth L: Does the authenticity of preclinical teaching format affect subsequent clinical clerkship outcomes? Teach Learn Med 2012, 24:177-182.

14. Hopavian K, Howe A, Dagley V: A survey of UK medical schools' arrangements for early patient contact. Med Teach 2007, 29:806-813. 
15. Carraccio C, Wolfsthal SD, Englander R, Ferentz K, Martin C: Shifting paradigms: from Flexner to competencies. Acad Med 2002, 77:361-367.

16. Kusurkar RA, Croiset S, Mann KV, Custers E, Ten Cate O: Have motivational theories guided the development and reform of medical education curricula? A review of the literature. Acad Med 2012, 87:735-743.

17. Dobie SA, Carline JD, Laskowski MB: An early preceptorship and medical students' beliefs, values, and career choices. Adv Health Science Educ Theory Prac 1997, 2:3547.

18. Goldstein EA, Maclaren CF, Smith S, Mengert TJ, Maestas RR, Foy HM, Wenrich MD, Ramsey PG: Promoting fundamental clinical skills: a competency-based college approach at the University of Washington. Acad Med 2005, 80:423-433.

19. Miller BM, Moore DE Jr, Stead WW, Balser JR: Beyond Flexner: a new model for continuous learning in the health professions. Acad Med 2010, 85:266-272.

20. Frank JR, Snell LS, Cate OT, Holmboe ES, Carraccio C, Swing SR, Harris P, Glasgow NJ, Campbell C, Dath D, Harden RM, Iobst W, Long DM, Mungroo R, Richardson DL, Sherbino J, Silver I, Taber S, Talbot M, Harris KA: Competency-based medical education: theory to practice. Med Teach 2010, 32:638-645. 


\section{Chapter 3}

Ready or Not? Expectations of Faculty and Medical Students for Clinical Skills Training for Medical Students

M Wenrich, MB Jackson, AL Scherpbier, IH Wolfhagen, PG Ramsey, EA Goldstein

Published in Med Ed Online 2015;15:S295 


\begin{abstract}
Background: Preclerkship clinical-skills training has received increasing attention as foundational preparation for clerkships. Expectations among medical students and faculty regarding the clinical skills and level of skill mastery needed for starting clerkships are unknown. Medical students, faculty teaching in the preclinical setting, and clinical clerkship faculty may have differing expectations of students entering clerkships. If students' expectations differ from faculty expectations, students may experience anxiety. Alternately, congruent expectations among students and faculty may facilitate integrated and seamless student transitions to clerkships.
\end{abstract}

Aims: To assess the congruence of expectations among preclerkship faculty, clerkship faculty, and medical students for the clinical skills and appropriate level of clinical-skills preparation needed to begin clerkships.

Methods: Investigators surveyed preclinical faculty, clerkship faculty, and medical students early in their basic clerkships at a North American medical school that focuses on preclerkship clinical-skills development. Survey questions assessed expectations for the appropriate level of preparation in basic and advanced clinical skills for students entering clerkships.

Results: Preclinical faculty and students had higher expectations than clerkship faculty for degree of preparation in most basic skills. Students had higher expectations than both faculty groups for advanced skills preparation.

Conclusions: Preclinical faculty, clerkship faculty and medical students appear to have different expectations of clinical-skills training needed for clerkships. As American medical schools increasingly introduce clinical-skills training prior to clerkships, more attention to alignment, communication, and integration between preclinical and clerkship faculty will be important to establish common curricular agendas and increase integration of student learning. Clarification of skills expectations may also alleviate student anxiety about clerkships and enhance their learning. 


\section{BACKGROUND}

Mastering clinical skills is fundamental to becoming a physician. While many medical schools continue to follow the Flexner model of teaching basic sciences in the first 2 years of medical school, the preclinical period is also a critical time for providing students with a solid introduction to and foundation in core clinical skills. ${ }^{1}$ In recent years, early clinicalskills training has received increased attention, partially due to clerkship directors' concerns about the clinical skills of students entering clerkships..$^{2-3}$ Despite the widespread importance cited for preclerkship skills preparation and increased calls for integration between the preclinical and clerkship stages of training, few schools vertically integrate their clinicalskills curricula by establishing, coordinating, and communicating expectations for breadth and depth of skills training across the preclerkship and clerkship periods. ${ }^{4}$

While transparent statements in educational settings about expected competencies are important, there is little formal guidance about which competencies early clinical-skills training should focus on and to what extent. ${ }^{5-7}$ Since learning occurs by the construction of new knowledge and skills on prior knowledge and skills, ${ }^{8,9}$ the objectives of preclinical skills development are optimally correlated and aligned developmentally with basic clerkship goals. The more curricula are aligned or mapped, with clearly delineated scope and sequence, the more students will relate new learning to prior learning and build advanced understanding. ${ }^{10}$ Harden outlined the integration ladder that defines the various levels of integration, from polarization to fully integrated teaching. ${ }^{11}$ Temporal coordination - parallel teaching or concurrent teaching — defines timing for teaching topics within a subject; equally important is temporal coordination of competencies across training levels, which requires full understanding of the curriculum by teachers at different levels.

While no dominant methods have emerged for preclerkship clinical-skills training, a successful clinical-skills curriculum may use a variety of formats and settings, with clearly defined learning objectives for each activity and learning opportunities based on ability to help students achieve objectives. ${ }^{12}$ Preclerkship contact with real patients enhances integration of theory and practice, knowledge construction and clinical reasoning, increases student motivation, and provides acclimation to clinical environments. ${ }^{13-15}$ Ideally, early patient contact occurs in the context of a series of educational experiences that build on one another. ${ }^{16}$

"Guided bedside learning" uses learning communities to deliver a preclerkship clinical-skills curriculum. ${ }^{17-19}$ Under the guidance of a consistent faculty mentor, preclerkship medical students learn clinical skills at the bedside in the context of real patients through a year-long, progressive, developmental process. During training, students receive a mix of clinical-skills laboratory preparation, bedside guidance from their faculty mentor, and limited independence with the patient, using explicit competency standards. Guided bedside learning 
has been associated with improved student performance in basic clerkships and increased comfort starting clinical clerkships. ${ }^{20-21}$

As early clinical-skills training programs emerge nationally and internationally, it is important to assess the extent to which preclinical and clerkship faculty share common expectations and understanding about the ideal breadth and depth of clinical skills appropriate for the start of clinical clerkships. Alignment between preclinical and clerkship faculty should make the transition to clerkships smooth and enhance students' clerkship experience and learning. As medical schools grow and faculty who are already spread thin with clinical, research, and teaching responsibilities are asked to assume more teaching, maintaining clarity and coordination of objectives for clinical skills at each level of medical education becomes imperative.

Prince and colleagues described medical student anxiety as they transition to clerkships. ${ }^{22}$ Some of this may result from unclear understanding of skills expected of students in clerkships. O'Brien and colleagues ${ }^{23}$ highlighted the complex and multifaceted struggles students face as they start clerkships and called for improved communication between students and teachers early in clerkships, especially in helping students develop standards and skills for self-assessment. Development of common expectations for clinical-skills preparation between students and faculty is one pathway to reduce student anxiety, ease the transition, and maximize efficient skill improvement.

In our study, we asked three questions: What are teacher and learner expectations of clinicalskills training in preparation for clerkships? Are preclinical faculty expectations similar to those of clerkship faculty for clinical-skills preparation? What are the expectations of medical students compared with preclinical and clerkship faculty?

\section{METHODS}

\section{Context}

This study was conducted at the University of Washington School of Medicine, a large, North American medical school with a preclinical curriculum that incorporates clinical-skills preparation in the preclinical setting through its colleges program. ${ }^{17}$ Thirty-seven faculty mentors work in a learning community setting to establish and implement a dynamic curriculum, teach clinical skills to second-year students, and provide ongoing mentoring. Students receive clinical-skills preparation in the inpatient setting in the context of real patients and using the curricular approach of guided bedside learning in preparation for clerkships. The core components of the guided bedside learning in the colleges program are shown in Table 1. The curriculum focuses most strongly on history taking, physical examination, communication skills, oral case presentation, and write-ups, with some focus as the year progresses to an introduction to clinical reasoning. 
Table 1: Characteristics of the preclinical "Guided Bedside Learning" approach to clinical skills training.

- Oriented to foundational clinical-skills training

○ Basic clinical-skills development driven by competencies and developmental progression

- Clinical-skills competency domains:

- Interviewing skills

- Physical examination

- Oral case presentation

- Clinical reasoning

- Documentation, including complete write-up

- Progression of skills training from basic skills to introduction to advanced skills, with spiral approach to training and assessment ${ }^{23.24}$

- Standardized curriculum

- Students receive objective, written standards

("benchmarks") for clinical skills to be mastered prior to clerkships. These benchmarks, tied to competencies and developed by the college faculty, serve as the basis for students' clinical preparation in the skills lab and at the bedside $^{16}$

- Formative and summative evaluation of students by mentors is based on competencies/benchmarks

- Active learning with real patients

- Combination of monthly organ-specific 'advanced exam' teaching sessions in a skills-lab practice setting and weekly half-day bedside teaching encounters with inpatients

- Students assume responsibility for interviewing and performing physical examinations on consenting inpatients with partial or full observation by faculty mentor

- Students present patient at the bedside to faculty mentor and student small group, and submit a write-up to their mentor for review, feedback

- Each student is directly responsible for at least six patients across 9 months and observes peers presenting patient at the bedside $>/=30$ times

- Guidance from mentors with limited introduction to 'graded responsibility'

- Preliminary mentor-led organ-based skills lab sessions are followed by work with real patients

- Students are alone at the bedside some of the time, performing a history and physical examination, with mentors rotating between two students and providing guidance as needed

- Mentors provide verbal feedback at bedside and after oral case presentation, and critique write-ups 


\section{Overview of research}

We conducted one-time, online, anonymous surveys of 1) preclinical faculty responsible for teaching clinical skills to second-year students through the guided bedside teaching approach; 2) basic clerkship site directors who assume overall responsibility for all medical students within a clerkship at one geographic location; and 3) medical students approximately 3 months into the start of their clerkships. By surveying students who had recently started clerkships, we hoped to capture students at a point at which they had insight into what skills are necessary and appropriate for starting their clinical years, while minimizing recall bias regarding the specifics of their pre-clinical training.

\section{Instruments}

Investigators (MDW, MBJ, EAG) developed three similar instruments for online administration. For each participant group, we asked what level of preparation they expected for medical students for the start of clerkships in a variety of clinical skills related to competencies, from basic (i.e., take a comprehensive history) to advanced (i.e., developing a differential diagnosis). The Likert rating scale for all three surveys was $1=$ none to $5=$ considerable preparation. The question wording was modified slightly to reflect the composition of each group. (see Appendix 1) For the purposes of this paper, all of these will be referred to as 'expectations for student preparation.'

Clinical skills were based on the primary topics relevant to developing basic clinical skills. They were reviewed and modified by two clinician-investigators (MBJ, EAG) as well as by several medical educators and clinician-educators, including physician and non-physician members of the medical school's basic required clerkship curriculum committee.

Demographic questions concerning teaching experience and settings were developed for teaching faculty in order to assess whether clinical teaching experience or years teaching might explain any findings in primary analyses. In addition, basic demographic information (such as gender) was collected for all participants.

\section{Recruitment and subjects}

All recruitment was conducted by e-mail. For each subject group, we requested participation in an anonymous, online research survey with the intention of promoting quality improvement and common understanding of expectations of clinical skills for the start of clerkships. Student participants received a US\$5 coffee card for completing the survey. A blinded method was employed to distribute coffee cards to students in order to ensure anonymity. The faculty received no compensation. All surveys and methods were approved as exempt by the University of Washington Human Subjects Division. 
For each group, we sent an initial e-mail and two follow-up requests approximately two weeks apart. In April 2008, we requested participation of all 33 college faculty membersthe preclinical faculty - who taught second-year medical students at that time. To recruit clerkship faculty, we identified required clerkship directors at each clerkship location. Initial mailings went to 97 clerkship site directors within six clerkships (internal medicine, family medicine, surgery, psychiatry and behavioral sciences, pediatrics, and obstetrics \& gynecology). To recruit medical students, we e-mailed all 185 third-year medical students in their basic clerkship year in October 2008, approximately 3 months into clerkships.

\section{Data analysis}

Anonymous surveys were prepared using Catalyst, a Web-based application for course and research surveys created at the University of Washington. Completed survey results were converted to SPSS files, and analyses were performed using SPSS Version 16 for Windows. Comparisons of ratings by clerkship faculty, preclinical faculty, and medical students were performed using one-way analysis of variance; post-hoc comparisons were performed using the Bonferroni correction. A standard alpha of .05 was used for statistical significance.

\section{RESULTS}

\section{Participants and non-respondents}

Fifty-six of 97 (58\%) clerkship faculty completed surveys. Among 33 preclinical faculty serving as college mentors at the time of the study, 30 (91\%) completed surveys. Of 185 medical students, $115(62 \%)$ completed surveys.

Among the faculty, $50 \%$ of preclinical faculty and $35.2 \%$ of clerkship faculty were women. Among medical students, 59.1\% were women.

Review of the teaching experience of preclinical and clerkship faculty revealed that in both groups, $90 \%(n=27)$ of preclinical faculty and $82.1 \%(n=46)$ of clerkship faculty had $5+$ years of experience teaching in a clinical setting with medical students at any level and/or residents at any level. Most $(83.3 \%, \mathrm{n}=25)$ preclinical faculty also taught students in basic clerkships. These demographic variables were therefore not used to further examine possible relationships to ratings.

Because 14 of the clerkship faculty (25\%) did not teach preclinical students in addition to students in basic clerkships, we compared ratings of the expectations of students' training by these faculty members with ratings by the clerkship faculty who also taught preclinical students. Results were similar between the two subgroups, suggesting that teaching setting did not contaminate groups in primary analyses. 
For medical students and clerkship faculty, the demographic and teaching characteristics of respondents were compared to those of the entire groups to which surveys were mailed. Medical student respondents were compared with the entire class by gender and preclinical first-year education site (Seattle versus non-Seattle). Clerkship faculty respondents were compared with the entire group of clerkship faculty by gender and number of years teaching clinical medicine (less than 5 years compared with $5+$ years). Characteristics were similar, suggesting that respondents are representative of the groups as a whole. Because of the high response rate, we did not perform this comparison for preclinical faculty.

\section{Expectations for clinical-skills preparation}

As shown in Table 2, statistically significant differences were found in all but three clinical skills areas in expectations of clinical-skills preparation for students starting clerkship. A visual representation of comparative data is shown in Fig. 1. Both preclinical faculty and medical students had higher expectations than clerkship faculty for preparation in all basic clinical skills except communication skills, working as a team member, and receiving feedback. No significant differences were found between the groups in expectations for communication skills or working as a team member. For receiving feedback, preclinical faculty had higher expectations than students. 


\section{Table 2}

\section{Perceptions of extent of clinical skills preparation appropriate for students beginning} clerkships in basic and advanced clinical skills and in basic science knowledge ${ }^{\mathrm{a}}$

\begin{tabular}{|c|c|c|c|c|}
\hline Skill Area & $\begin{array}{l}\begin{array}{l}\text { Preclinical } \\
\text { faculty } \\
\mathbf{n}=\mathbf{3 0} \\
\text { Mean (SD) }\end{array}\end{array}$ & $\begin{array}{l}\text { Clerkship } \\
\text { faculty } \\
\mathbf{n = 5 6} \\
\text { Mean (SD) }\end{array}$ & $\begin{array}{l}\text { Third-year } \\
\text { students } \\
\mathbf{n}=115 \\
\text { Mean (SD) }\end{array}$ & Alpha \\
\hline \multicolumn{5}{|l|}{ Basic clinical skills } \\
\hline Communication skills & $4.27(0.83)$ & $4.0(0.86)$ & $4.22(0.9)$ & Ns \\
\hline $\begin{array}{l}\text { Taking a comprehensive } \\
\text { history }\end{array}$ & $4.5(0.57)$ & $3.93(1)$ & $4.66(0.56)$ & $.000^{\mathrm{c}, \mathrm{d}}$ \\
\hline Complete review of systems & $4.53(0.57)$ & $3.91(0.98)$ & $4.32(0.82)$ & $.002^{\mathrm{c}, \mathrm{d}}$ \\
\hline $\begin{array}{l}\text { Performing a full physical } \\
\text { exam }\end{array}$ & $4.43(0.57)$ & $4(0.97)$ & $4.57(0.66)$ & $.000^{\mathrm{c}, \mathrm{d}}$ \\
\hline $\begin{array}{l}\text { Comprehensive oral case } \\
\text { presentation }\end{array}$ & $4.33(0.55)$ & $3.45(0.89)$ & $4.49(0.71)$ & $.000^{\mathrm{c}, \mathrm{d}}$ \\
\hline Complete write-up & $4.57(0.63)$ & $3.75(0.93)$ & $4.37(0.72)$ & $.000^{\mathrm{c}, \mathrm{d}}$ \\
\hline Working as a team member & $3.7(1)$ & $3.96(1)$ & $3.84(1)$ & Ns \\
\hline Receiving feedback & $4.57(0.57)$ & $4.23(0.87)$ & $4.01(1.1)$ & $.017^{\mathrm{e}}$ \\
\hline \multicolumn{5}{|l|}{ Advanced clinical skills } \\
\hline Focused history & $3.93(0.79)$ & $3.3(1)$ & $4.49(0.9)$ & $.000^{\mathrm{b}, \mathrm{c}, \mathrm{d}}$ \\
\hline Focused physical exam & $3.83(0.83)$ & $3.18(1.1)$ & $4.41(0.91)$ & $.000^{\mathrm{b}, \mathrm{c}, \mathrm{d}}$ \\
\hline $\begin{array}{l}\text { Focused oral case } \\
\text { presentation }\end{array}$ & $3.47(0.9)$ & $2.95(0.9)$ & $4.19(1)$ & $.000^{\mathrm{b}, \mathrm{c}}$ \\
\hline Preparing SOAP notes & $2.87(0.97)$ & $3.45(1)$ & $4.18(1)$ & $.000^{\mathrm{b}, \mathrm{c}, \mathrm{f}}$ \\
\hline Clinical reasoning & $3.2(0.66)$ & $2.96(0.81)$ & $4.34(0.8)$ & $.000^{\mathrm{b}, \mathrm{c}}$ \\
\hline $\begin{array}{l}\text { Preparing assessment and } \\
\text { plan }\end{array}$ & $2.6(0.62)$ & $2.75(0.79)$ & $4.07(1.1)$ & $.000^{b, c}$ \\
\hline Differential diagnosis & $3.17(0.65)$ & $2.89(0.85)$ & $4.26(0.96)$ & $.000^{\mathrm{b}, \mathrm{c}}$ \\
\hline \multicolumn{5}{|l|}{ Knowledge-related } \\
\hline Basic science knowledge & $4.17(0.8)$ & $3.95(0.8)$ & $4.2(0.86)$ & Ns \\
\hline \multicolumn{5}{|c|}{$\begin{array}{l}\text { a Mean ratings on Likert scale } 1=\text { none....5=considerable in response to questions about } \\
\text { expectations concerning students' preparation in skill areas and basic science knowledge } \\
\text { for beginning of third-year clerkships. Alpha }<.05 \text {. All post-hoc tests used Bonferroni } \\
\text { correction for multiple comparisons. } \\
\text { b Students higher than preclinical faculty } \\
\text { c Students higher than clerkship faculty } \\
\text { d Preclinical faculty higher than clerkship faculty } \\
\text { e Preclinical faculty higher than students } \\
\text { f Clerkship faculty higher than preclinical faculty }\end{array}$} \\
\hline
\end{tabular}


Figure 1: Extent of clinical skills preparation perceived as appropriate for students for the start of clerkships.

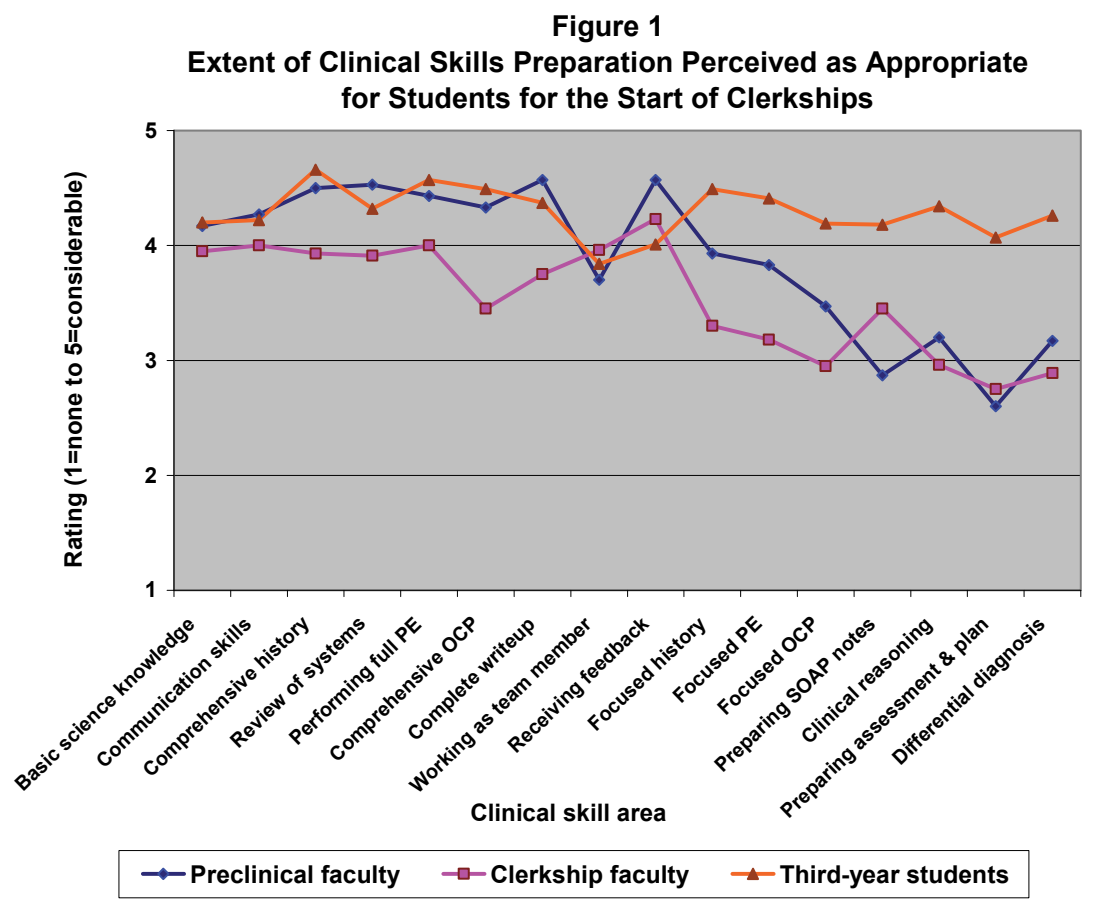

In assessing expectations for training in advanced clinical skills for the start of clerkships, there were significant differences in all seven clinical-skills areas. In all areas, students had significantly higher expectations than either preclinical faculty or clerkship faculty. In two areas (focused history and focused physical exam), the preclinical faculty had significantly higher expectations than the clerkship faculty. In one area (preparing SOAP notes), clerkship faculty had significantly higher expectations than the preclinical faculty.

For basic science knowledge, there were no significant differences between the three groups in the extent of preparation perceived as appropriate for a student beginning clerkships. 


\section{DISCUSSION}

In a curriculum in which preclerkship clinical-skills training has been shown to improve students' early comfort with and performance in clerkships, ${ }^{20-21}$ we found substantial differences in the expectations for clinical-skills preparation for clerkships between preclinical faculty, clerkship faculty, and medical students. Preclinical faculty and medical students had significantly higher expectations than clerkship faculty for preparation in most basic clinical skills. Students had significantly higher expectations than both faculty groups for advanced clinical skills.

The small number of differences between preclinical and clinical faculty for expectations of training in advanced clinical-skills suggests that preclinical and clerkship faculty commonly perceive that teaching advanced skills is most appropriate for the clerkship setting.

The lack of congruence between preclerkship and clerkship faculty for preparation in basic clinical skills suggests a curriculum in transition. A developmental, spiral curriculum, as posited by Harden and colleagues, requires congruence between different training settings, whether preclinical to clinical, or undergraduate to postgraduate. ${ }^{17,24,25}$ Communication across different levels is important, but in this case, may not have sufficiently occurred. This has important implications for the many medical schools currently or considering undertaking curriculum reviews and reform. Curricular reforms have the potential to initiate change in either portion of a curriculum or comprehensively. For example, in today's dominant " $2+2$ " Flexnerian curriculum, reform may be limited to either the first two years or the second two years. The colleges curricular innovation most strongly focuses on skills training in the preclerkship period. Data from this study indicate the need to consider curricular reforms holistically and in the case of early clinical-skills training, integrate efforts and communicate closely with clerkship faculty. Processes, such as curriculum mapping, may be used when curricular changes occur so that innovations are fully aligned and integrated with other parts of the curriculum. ${ }^{10}$

Students had higher expectations for advanced skill preparation than both faculty groups. Providing sustained guided bedside learning did not reduce students' expectations of 
advanced preparation. This may emanate from transition anxiety or "shock of practice" of students as they enter clerkships and the perception of being unprepared for and inadequate in skills they are exposed to in clerkships. ${ }^{26}$ Because students were surveyed partway into their first year of clerkships rather than at the start of the first year of clerkships, this is unlikely. Finally, students may have had insufficient communication by preclinical and clerkship faculty concerning skills and skill levels expected for the start of clerkships, leading to high expectations for preparation in both basic and advanced clinical skills.

Overall, data suggest that even when clinical skills are taught within the preclinical curriculum in a curriculum with clear competency standards, there may be discrepancies between expectations of students and faculty concerning skills that should be addressed and the extent to which students should receive preparation. This highlights the need to consider and coordinate the full range of activities and curricula related to clinical-skills development, from first-year training to the final year of medical school. While this point has been highlighted in relationship to basic science education, it needs to be considered more fully for clinical-skills development.

Our data also support the findings of $\mathrm{O}^{\prime} \mathrm{Brien}_{\mathrm{et}} \mathrm{al}^{23}$ that improved communication between students and faculty would benefit students in knowing the standards expected of them. In our setting, both preclinical and clerkship faculty need to discuss with and explain expectations to students. As more medical schools strengthen and refine early clinical-skills programs, communicating expectations at each point of training, including for the start of clerkships, will assume greater importance.

Before these communications occur, preclinical and clerkship faculty must agree on expectations. Discussions between preclinical and clerkship faculty could establish common expectations for student skills for the start of clerkships. One approach might be to have preclinical and clerkship faculty jointly develop and review competencies. This would require initial consensus on a philosophical foundation that accepts an integrated approach, works toward a seamless transition between preclerkship education and clerkships, and agrees on skills and levels appropriate at each developmental stage. 
This study has several limitations. The response rate varied by group: from an excellent response rate $(91 \%)$ from preclinical faculty to moderate response rates from students $(62 \%)$ and clerkship faculty (58\%). However, demographic and teaching characteristics of respondents were similar to the same characteristics for the entire groups to which surveys were mailed, suggesting that respondents and non-respondents were comparable. The data collected from students carry the possibility of recall bias. Students were asked to reflect back on their preclinical skills training, and to report their perception of the extent of clinical skills preparation appropriate for starting clerkships. This choice was deliberate; students who have not yet experienced clerkships are typically not yet in a position to report on which skills (and what level of skills) are needed in those settings. Further, students 3 months into clerkships may have had variable experiences in different clerkships, and thus variable perceptions on skills needed for starting basic clerkships. The survey instruments were designed using a simple Likert scale, with end anchors to help better clarify each clinical objective for students or faculty; this introduces the possibility of variable interpretations of each skill area.

The data presented here are for one medical school; studies are needed to confirm these findings in other settings with strong preclerkship focus on clinical-skills development and to ascertain whether increased communication about expectations across training levels results in increased congruence in expectations for student performance.

Curriculum reviews and reforms will benefit from holistic and vertically integrated approaches that consider all portions of the curriculum in relationship to one another. Students would benefit from improved communication with and from preclinical and clerkship faculty about expectations for clinical skills and proficiency at the start of clerkships. Both sets of faculty should reinforce this information. It is important for preclinical and clerkship faculty to develop a common philosophical understanding about the process and timing of clinical-skills development and delineation of responsibility. In a fully integrated, developmental model, clerkship faculty would have a strong sense of the preclinical curriculum for clinical-skills development and could help students to build upon and advance the skills taught by preclinical faculty. An intentional, ongoing dialogue between preclinical and clerkship faculty will optimize this process and enhance medical student education. 


\section{REFERENCES}

1. Omori DM, Wong RY, Aontonelli MA, Hemmer PA. Introduction to clinical medicine: a time for consensus and integration. Am J Med 2006; 118:189-194.

2. Windish DM, Paulman PM, Goroll AH, Bass EB. Do clerkship directors think medical students are prepared for the clerkship years? Acad Med 2004; 79:56-61.

3. Alexander EK. Perspective: moving students beyond an organ-based approach when teaching medical interviewing and physical examination skills. Acad Med 2008; 83:906909.

4. Cooke M, Irby DM, O'Brien BC. Educating Physicians: A Call for Reform of Medical School and Residency. San Francisco: Jossey-Bass, 2010.

5. Armstrong EG, Mackey M, Spear SJ. Medical education as a process management problem. Acad Med 2004; 79:721-8.

6. Matson, CC, Stearns J, Defer T, Greenberg L, Ullian JA. Prerequisite competencies for third-year clerkships: an interdisciplinary approach. Fam Med 2007;39:38-42.

7. Corbett EC Jr, Elnicki DM, Conaway MR. When should students learn essential physical examination skills? Views of internal medicine clerkship directors in North America. Acad Med 2008; 83:96-99.

8. Kaufman, DM. ABC of learning and teaching in medicine: Applying educational theory in practice. $B M J 2003 ; 326: 213-216$.

9. Prince, KJAH, Boshuizen HP. From theory to practice in medical education: Effect on knowledge application, clinical reasoning and learning. In: Boshuizen HPA, Bromme R, Gruber H, editors. Professional Learning: Gaps and Transitions on the Way from Novice to Expert. Dordrecht, The Netherlands: Kluwer Academic Publishers; 2004, p. 121-139.

10. Harden RM. AMEE Guide No. 21: Curriculum mapping: a tool for transparent and authentic teaching and learning. Med Teach 2001; 23:123-137.

11.Harden RM. The integration ladder: a tool for curriculum planning and evaluation. Med Educ 2000;34:551-7.

12. Task Force on the Clinical Skills Education of Medical Students. Recommendations for clinical skills curricula for undergraduate medical education: recommendations for preclerkship clinical skills education for undergraduate medical education. Washington, D.C.: Association of American Medical Colleges. 2008. 
13. Diemers AD, Dolmans DH, Verwijnen MG, Heineman E, Scherpbier AJ. Students' opinions about the effects of preclinical patient contacts on their learning. Adv Health Sciences Educ Theory Prac 2008; 13:633-647.

14.Diemers AD, Dolmans DH, Van Santen M, Van Luijk SJ, Janssen-Noordman AM, Scherpbier AJ. Students' perceptions of early patient encounters in a PBL curriculum: a first evaluation of the Maastricht experience. Med Teach 2007; 29:135-142.

15. Dornan T, Littlewood S, Margolis SA, Scherpbier A, Spencer J, Ypinazar V. How can experience in clinical and community settings contribute to early medical education? A BEME systematic review. Med Teach 2006; 28:3-18.

16. Kachur E. Observations during early clinical exposure - An effective tool or a bore? Med Educ 2003; 37:88-9.

17. Goldstein EA, Maclaren CF, Smith S, Mengert TJ, Maestas RR, Foy HM, Wenrich MD, Ramsey PG. Promoting fundamental clinical skills: a competency-based college approach at the University of Washington. Acad Med 2005;80:423-33.

18. Ferguson KJ, Wolter EM, Yarbrough DB, Carline JD, Krupat E. Defining and describing medical learning communities: results of a national survey. Acad Med 2009; 84:1549-56.

19. Irby DM, Wilkerson L. Educational innovations in academic medicine and environmental trends. J Gen Intern Med 2003;18:370-6.

20. Whipple ME, Barlow CB, Smith S, Goldstein EA. Early introduction of clinical skills improves medical student comfort at the start of third-year clerkships. Acad Med 2006; 18:S4-43.

21. Jackson MB, Keen M, Wenrich MD, Schaad DC, Robins L, Goldstein EA. Impact of a pre-clinical clinical skills curriculum on student performance in third-year clerkships. J Gen Inern Med 2009;26:929-33.

22. Prince KJ, Boshuizen HP, van der Vleuten CP, Scherpbier AJ. Students' opinions about their preparation for clinical practice. Med Educ 2005; 39:704-712.

23. O'Brien B, Cooke M, Irby DM. Perceptions and attributions of third-year student struggles in clerkships: Do students and clerkship directors agree? Acad Med 2007; 82:970-978.

24. Harden RM, Davis MH, Crosby JR. The new Dundee medical curriculum: a whole that is greater than the sum of the parts. Med Educ 1997; 31:264-271. 
25. Davis $\mathrm{MH}$, Harden RM. Planning and implementing an undergraduate medical curriculum: the lessons learned. Med Teach 2003; 25:596-608.

26. Prince KJAH, Van de Wiel MWJ, Scherpbier AJJA, Van der Vleuten CPM, Boshuizen HPA. A qualitative analysis of the transition from theory to practice in undergraduate training in a PBL medical school. Adv Health Sci Educ Theory Prac 2000; 5:105-116. 


\section{APPENDIX 1}

Questions posed to each group of raters to assess clinical skill areas.

Raters: Students early in third year

Based on your experiences as an early third year student, what level of preclinical preparation for clerkships should occur in each of the following? (Rating scale: $1=$ none to $5=$ considerable preparation.)

Raters: Preclinical faculty

For medical students at the completion of their second year, what level of preparation do you believe is appropriate for each of the following? (Rating scale: $1=$ none to $5=$ considerable preparation.)

Raters: Clerkship faculty

For third-year medical students at the beginning of their clinical year (i.e., in their first or second clerkship), what level of preparation do you expect in each of the following? (Rating scale: $1=$ none to $5=$ considerable.) 



\section{Chapter 4}

Teachers as Learners: The Impact of Bedside Teaching on the Clinical Skills of Clinician-Teachers

MD Wenrich, MB Jackson, KS Ajam, IH.

Wolfhagen, PG Ramsey, AJ Scherpbier

Published in:

Acad Med 2011;86: 846-852 


\section{ABSTRACT}

Purpose: To assess the impact on full-time faculty's own clinical skills and practices of sustained clinical skills bedside teaching with preclerkship students.

Methods: This was a longitudinal, qualitative study of faculty who provide dedicated ongoing bedside clinical skills teaching for preclerkship medical students. Interviews were conducted during 2003 to 2007 with 31 faculty of the Colleges program at University of Washington School of Medicine. Content analyses of interview transcripts were performed.

Results: Teachers perceived a strong positive impact of teaching on their own clinical skills. Six themes were associated with the influence of bedside teaching on teachers' skills and practices. One related to deterrents to change (e.g., reliance on tests/specialists) that narrowed teachers' practice skills prior to starting bedside teaching. Three related to expansion of the process of clinical care resulting from bedside teaching: expanded knowledge and skills, deconstructing the clinical experience (e.g., deepening, broadening, slowing one's practice), and greater self-reflection (e.g., awareness of being a role model). Two were perceived outcomes: improved clinical skills (e.g., physical examination) and more mindful practices (e.g., self-confidence, patient centered).

Conclusions: Teachers perceived profound and positive impact on their clinical skills from teaching preclerkship students at the bedside. Further studies are needed, including comparing teaching pre-clerkship students with teaching advanced students and residents, to assess whether teaching at other levels has this effect. 


\section{BACKGROUND}

Many studies have documented the decline in physicians' knowledge base and clinical skills over time due to the rapid growth of medical knowledge, fewer opportunities to practice basic skills later in physicians' careers, and other factors. ${ }^{1-5}$ Despite the strong need and call for lifelong learning and extensive use of continuing medical education by physicians, ${ }^{6-8}$ effective methods to implement lifelong learning remain elusive thanks to practice-based barriers and a lack of understanding of factors influencing learning.

Formal learning through time-limited, classroom-based courses shows limited effectiveness in improving practice outcomes. ${ }^{9-10}$ However, formal learning remains the dominant approach to lifelong learning. ${ }^{8}$ Less attention has focused on informal learning, which is frequently contextual, based in the learner's environment, and controlled by learners. ${ }^{11}$ Eraut ${ }^{12}$ describes three levels of intention in informal learning: (1) implicit learning, in which knowledge acquisition lacks both conscious attempts to learn and explicit knowledge of what was learned; (2) reactive, or opportunistic, learning, which is intentional but occurs spontaneously in the middle of an action; and (3) deliberative learning, which is intentional and has learning goals and planned time for acquiring new knowledge and engagement.

Deliberate practice - extensive, sustained practice of necessary skills, such as occurs during undergraduate and residency training - is essential to developing and maintaining expertise, yet data indicate that deliberate practice after medical school and residency training is rare. ${ }^{13}$ The motivation necessary to move beyond a performance "plateau" among practicing physicians may be introduced through experiencing doubt, uncertainty, or an emerging difficult event or problem, ${ }^{14}$ resulting in the commencement of a reflective process first characterized by Dewey. ${ }^{15}$ For some, this reflective process may initiate a learning process.

One potential arena for informal and contextual learning is the teaching environment, ${ }^{16}$ where teaching can gain added value if it initiates learning or provides contextual lifelong learning. The relevance of bedside teaching as a distinctive method for maintaining or advancing physicians' clinical skills has received little attention. Despite recommendations that teachers acquire bedside teaching skills and reinforce and update their clinical skills, ${ }^{17}$ physicians' discomfort with their skills and the reliance on laboratory tests, imaging, and consultative services to diagnose away from the bedside may deter physicians from undertaking bedside training. ${ }^{18}$ On the other hand, if bedside teaching improves physicians' own skills or stimulates learning, then it has advantages for students in skills instruction, for physicians and other members of the health care team in improving physicians' skills, and for patients in improved quality of care.

Several studies examined how teaching preclinical medical students in ambulatory settings affects community preceptors. Teachers reported increased morale, skills improvement, and 
positive practice infrastructure changes. ${ }^{19,20}$ Skills improvements were attributed to increased reading and reflection, receiving information and challenging questions from students, and increased time with patients. Students' questions made teachers observant of their work routines and patient management, elucidated shortcomings and knowledge gaps, and stimulated keeping up-to-date. Such preceptorships, however, frequently occur in outpatient settings. To our knowledge, no work has closely examined the impact of teaching medical students in inpatient settings on faculty's clinical skills.

In this qualitative study, we assessed the impact on full-time faculty's own clinical skills and practices of sustained clinical-skills bedside teaching with pre-clerkship students. Our research question was based on interviews with faculty over the initial five years of a bedside teaching program and asked how faculty perceive the impact of bedside teaching on their own clinical knowledge, skills and attitudes.

\section{METHODS}

\section{Curricular context}

At the University of Washington School of Medicine, some faculty train small groups of preclerkship students in clinical skills at the bedside through a curricular program called the Colleges. ${ }^{21}$ Students receive hands-on, one-on-one clinical experience, with close observation and feedback from their faculty mentor and small group of peers.

The Colleges approach has been described. ${ }^{21}$ Briefly, weekly throughout students' second year, two students within small groups are assigned one inpatient each from whom they take a history and physical examination; they then give a bedside oral case presentation, and complete a write-up. The faculty mentor both guides the students and gives them some independence so that learning is active and contextual. After students' bedside oral case presentations, the mentor and peers provide feedback, and the small group discusses the cases to advance students' clinical reasoning skills. Faculty also provide direct instruction and indirect teaching through role modeling in the patients' presence.

College faculty devote one-quarter of their professional time to teaching and mentoring students. Faculty are chosen through a competitive process open to all faculty in clinical specialties. Criteria include excellent teaching and clinical skills and interest in students. Faculty receive no special preparation for their roles and there is considerable latitude in teaching approaches and styles in specific skills areas; written clinical skills benchmarks provide content standardization. The faculty meet regularly to discuss common teaching issues and approaches and receive periodic faculty development, often from peer faculty. 
Most College faculty have worked with students in clerkships and with residents. Before the start of the Colleges, preclerkship clinical skills teaching occurred in community preceptorships; consequently, few College faculty worked with preclinical students. Therefore, the College curriculum and working with preclinical students' skill levels were new for most faculty. This curricular approach has been associated with improved student performance and greater comfort in clerkships. ${ }^{22,23}$

\section{Study approach}

A longitudinal qualitative study was undertaken at the start of the Colleges program in 2003 to understand how clinician-teachers approach teaching. The longitudinal design was used to explore how faculty's skills and teaching approaches change over time. Initial comprehensive data coding of all resulting transcripts was performed, with the intention of addressing more specific research questions related to the process and impact of teaching medical students. The study described in this paper addresses and explores faculty's perceptions of the impact of their bedside teaching on their own clinical knowledge, skills and attitudes.

One-on-one interviews were conducted with 31 College faculty members across five years, beginning at the end of the curriculum's first year. All College faculty during this time were invited to participate, and all who agreed to participate were selected. Interviews were conducted in summer 2003, fall 2004, and summer 2007, with the intention of conducting interviews approximately annually. Summer and fall interviews permitted reflection on the year just completed. In 2006, focus groups were held in place of interviews; results from those focus groups are not analyzed here because of the different format.

\section{Instruments and data collection}

Semi-structured interview questions were developed by two educators and two clinical faculty and were modified each year to address emerging themes. Questions were piloted in early interviews. The initial question relevant to this study in first-year interviews was, "To what extent has working as a College faculty member influenced your own clinical skills?" The second interviews contained no questions about impact of teaching on faculty skills and clinical practices; however, those interviews were reviewed for comments about the impact of teaching on faculty clinical skills. The third interviews included no formal questions about impact of teaching on clinical skills, but many faculty were probed concerning changes in their clinical skills as a result of teaching at the bedside.

Five experienced interviewers conducted one-on-one interviews. Audiotaped 20-40 minute interviews were transcribed without identifiers. Interviews were scheduled for 30 minutes; differences in lengths of interview were based on interviewee's time constraints and verbal responses. Basic demographic data were collected. 
The University of Washington institutional review board approved all instruments and procedures.

\section{Data analysis}

Three investigators reviewed all transcripts and coded passages using constant comparison and axial coding, techniques derived from grounded theory research. ${ }^{24}$ The emergent code relevant to this study from all three years was "mentor clinical skills." This code related to the influence of teaching on physicians' own clinical skills.

Investigators isolated this code and reviewed relevant passages for themes. One investigator reviewed and coded all relevant passages; the other two investigators each reviewed and coded half of the passages. As themes emerged, discrepant data were isolated, discussed and if deemed significant, noted in the results. The three investigators then compared codes and developed a common code structure, isolating characteristic transcripts for each code. Codes were organized into larger clusters, or themes, and related to one another. Investigators also examined quotes for individual physicians over time and quantified positive, neutral, and negative comments concerning the impact of teaching on clinical skills. The longitudinal nature of the study provided a measure of validity through examination for recurrent themes. For further validation, after the study's conclusion, as part of an annual survey, College faculty were asked, in an open-ended survey question, what effect working as a College faculty had on their own clinical skills and work with their own patients, if any. Of 31 responses, 26 described positive change; 5 did not respond to the question. There were no negative responses. A conceptual model was developed to characterize the relationships between themes.

\section{RESULTS}

\section{Participants and demographic characteristics}

All 31 College faculty agreed to participate; not all faculty were able to complete interviews because of availability and faculty turnover; therefore, interviews for some faculty are available for only one or two years. Twenty-nine faculty were interviewed two to three times and two were interviewed once (total 82 interviews). Demographic characteristics of participants are shown in Table 1. 
Table 1: Demographic characteristics of 31 participants in a University of Washington qualitative study of the effects of preclinical bedside teaching on clinician-teachers' knowledge and skills, 2003-2007

\begin{tabular}{lc} 
Characteristic & No. $(\%)$ \\
Gender & $14(45)$ \\
Male & $17(55)$ \\
\hline Female & $13(42)$ \\
\hline Years teaching & $18(58)$ \\
\hline 10 or fewer & \\
\hline More than 10 & $20(64.5)$ \\
\hline Specialty* & $11(35.5)$ \\
\hline Primary care & \\
\hline Other &
\end{tabular}

*Primary care includes general internal medicine, pediatrics, family medicine, and emergency medicine. Specialty care includes surgery, rehabilitation medicine, psychiatry, neurology, obstetricsgynecology, anesthesiology, dermatology, and otolaryngology.

\section{Themes}

Six themes were associated with the influence of teaching on teachers' own skills and practices. Themes and sub-themes are shown in List 1 and are examined in detail here. 
List 1: Themes and subthemes identified from qualitative analyses related to effects of preclinical bedside teaching on teachers' clinical knowledge and skills, University of Washington, 2003-2007

1. Change deterrents

- Focus on one's specialty/expertise

- Automated practice

- Reliance on tests and specialists

2. Constructing knowledge and skills

- Self-directed learning of knowledge/skills

- Learning from students

- Learning from peers

3. Deconstructing the clinical experience

- Developing slower practice timeframe

- Reducing clinical care to a more basic level

- Increased awareness of process of care

- Greater breadth/depth of knowledge, skills, practice

4. Practicing with a third eye

- Awareness of being a role model

- Seeing/thinking about patients from students' eyes

5. Skills improvement

- Physical examination

- Interviewing/communication

- Critical reasoning

6. Implementing the mindful practice

- Self confidence/comfort with challenges

- More patient-centered approach

- Greater practice enjoyment

\section{Change deterrents}

Participants described factors deterring their ability to maintain skills and gain new knowledge prior to teaching within the Colleges. One deterrent was the focus in one's own area of expertise or frequent usage of a narrow range of skills, whether in teaching or practice, so that other skills became foreign or were forgotten. One participant said

I have gotten lazy over the years. We were talking about how you make the diagnosis. They say 90 percent, but more like 98 percent of the time [comes] from history. A lot of the time I wasn't doing much physical exam in my own clinic. 
Advanced-level teaching also constrained the breadth of skills used: "Third- and fourth-year students are more interested in my...little narrow area. You assume they have some basic knowledge...."

A second deterrent was "automated practice" - the fast pace of practice, routines, and mechanical thought processes. Practice skills were lost through shortcuts:

[Before joining the Colleges] I came at patients very physician-centered. "I have so much time to see you and I'm going to start asking questions right away" versus "Tell me what's going on."

Clinical reasoning also became automated:

...you're taking in information in a fast-moving clinic and going with some clinical judgment and you don't realize... all the factors you're putting together to make an assessment and move on.

A third deterrent was reliance on tests, procedures, and consultants/specialists:

Maybe you heard a systolic murmur and [thought] "Let's get an ultrasound" instead of running through, "What are the provocative tests I could do that would heighten my likelihood of being right?"

\section{Constructing knowledge/skills}

The second theme related to learning in preparation for, or resulting from, teaching. Two subthemes focused on primary learning mechanisms: self-directed learning and learning from students and peer faculty.

Self-directed learning often involved preparing for bedside teaching related to the organbased curriculum (e.g., cardiovascular, gastroenterology) through reviewing books, notes, and other resources. Many faculty described refreshing, refining, and relearning knowledge they had not been responsible for since training: "I'm reviewing stuff I haven't reviewed in years. And it's making me a better clinician."

Many physicians had forgotten or become rusty at knowledge/skills from earlier training or practice phase:

I found myself going back and reminding myself of physical diagnosis tests you don't use very frequently...Even going back and reminding yourself about the logical sequence of [deciding] when a murmur is clinically significant... 
In the second subtheme, faculty described learning from students and peers. Medical students introduced recent or revised knowledge. One faculty said, "[Students] teach me stuff they've learned in classes, things that weren't known 20 years ago."

Peer faculty played an educational role. Among diverse specialties, teachers learned from peers in areas they were teaching students at the bedside. Faculty refreshed knowledge and skills, learned new material, and sometimes learned that their clinical techniques/methods were no longer the standard of care. A physician said:

To hear [a peer] talk about what is important in a [specialty] exam...you find out [that] things you've been doing for years out of force of habit, he thinks are a waste of time.... (Laughs) Why have I been doing it then?

\section{Deconstructing the clinical experience}

Working with students led faculty to examine their own clinical practice styles - reflecting on their thinking and practice. Four subthemes emerged: developing a slower practice time frame, increased awareness or consciousness of the clinical process, reducing care to a more basic level, and expanding and deepening one's practice.

In the first subtheme, working with students caused physicians to slow down: "I wanted to spend more time in clinical practice savoring that part of the exam." Another physician realized that his fast pace negatively affected skills: "My clinical skills had gotten sloppy....I'm always rushing around like an idiot. I've slowed down. I've listened to people more. I've felt people more carefully."

The second subtheme related to increased awareness of the patient care process. Physicians thought more about what they were doing: "I'm more careful in my physical exam. It's more entertaining to know deliberately what you're doing and why." As a result, physicians provided more thorough yet focused care:

... if I'm doing an HEENT [head, eyes, ears, nose, and throat] exam, it's a more complete HEENT exam. If it's a cardiac exam, it's a more complete cardiac exam than I did before .... [I]t's like rediscovering something, you're more attentive; you're more focused on it.

The third subtheme, breaking clinical care down to a more basic level, meant thinking consciously rather than relying primarily on tacit knowledge, pattern recognition, and other cognitive short-cuts. Several physicians used the word "dissect": "We spend our time trying to dissect that interaction between the physician and the patient for the sake of our students. And it helps me dissect that in practice, as well." 
The fourth subtheme related to greater breadth and depth of knowledge, skills, and practice resulting from seeing a wider swath of practice and learning skills. This had several meanings. One was that in order to teach, one must know a subject well and in depth: "If you have to teach something, you have to know it cold, or you get halfway through and you're lost and get embarrassed." Physicians teaching at the bedside with types of patients atypical for their practice found that their sphere of practice, whether primary care or specialty-based, expanded; this expanded breadth of knowledge:

I see a lot of diseases and conditions [with students] that would never come across my path.... And then we can relate it to what we're learning in physical diagnosis and that makes it come alive. I'm a better clinician for it.

\section{Practicing with a third eye}

This theme related to heightened self-awareness that translated from teaching to patient encounters and seeing oneself from the perspectives of others. Two sub-themes emerged: awareness of being a role model and holding to that high standard at all times, and seeing patients through students' eyes.

In the first subtheme, physicians became conscious of the standard they set for students, holding to that standard in their practice: “....if I feel frustrated or irritated with a patient, sometimes my experience with students will make me say the same things to myself about being patient, being understanding." Awareness of being a role model elevated physicians to continued consciousness of working at a high standard:

If you are expounding on the virtues of doing things a certain way, you gotta do it that way. I've become better at catching myself, if I'm ever slipping away from doing things in a good way.

In the second subtheme, physicians saw their patients through students' eyes. This might involve wishing a student was present for a teaching opportunity or thinking about how one might articulate, explain, or describe a patient:

I just examined somebody who had probably early Parkinson's syndrome. I'm thinking, how do you describe that, dissecting that clinically, how would I describe [it to] my students, how would I even tell them how I know what I know? Or how would I get them to know that?

\section{Skills improvement}

The theme of perceived improvement of teachers' clinical skills focused on three primary areas: physical examination, interviewing/communication, and critical thinking. 
Physical examination improvement, the most frequently mentioned clinical skills outcome, involved advancing exam skills and increased willingness to perform physical exam:

... some of the skills...you just taught them so they're available to you, in your own practice. Sometimes I'll do more things on the exam than I might have otherwise, so my physical exam skill set has increased.

The impact was more active involvement for a disease or condition that the physician might normally quickly refer to a specialist:

....it was no longer, just palpating and looking for the gross stuff and saying, "You need an orthopedics referral." Now it was, "Before I send you to orthopedics, which I may anyway, I want to look for muscle atrophy and fasciculation." I want to see if he had impingement. I want to see how much I can figure out myself.

Specific physical examination skills most frequently identified as improved were musculoskeletal, cardiac, and neurological; many physicians described general physical exam improvement.

Although many physicians felt they were already at a high level in interviewing, they frequently mentioned improved interviewing/communication: "[Teaching] changed me... [W] hen I approach patients, I'm more consistent in starting out very open-ended. I'm more intentional rather than having it as a subconscious thing."

The third area was critical thinking. A physician said:

There are times I'll reflect back and I made up my mind in the first 30 seconds, but then I'll think, "Oh, so what do I do about that?" Then I structure the rest of my time with the patient to get through stuff. It keeps me thinking, "What pieces do I need for this? What pieces do I pull out, in my short times with patients?"

Another physician described change in self-articulation of reasoning: “. ..you're more stepwise in your reasoning, you're saying, 'It's not this because of this. It's not this because of that."”

\section{Implementing the mindful practice}

Clinician-teachers perceived a strong impact of bedside work with preclerkship students on their overall patient care approach, describing a more conscious, mindful approach: “...it changes my attitude...it's all tied up with mindfulness and being aware of my own feelings and why I'm feeling that way." Others described this as greater awareness or acuity: "I find 
myself getting very, very clear stories on my patients. It's not that I didn't before; I'm more aware that that's what I'm doing..."

Subthemes were expression of greater self-confidence and comfort with challenges, using a more patient-centered focus, and greater practice enjoyment. Self-confidence manifested itself through greater comfort with difficult patients:

I get a list of patients that day. And invariably, you look down and go, "Oh, there's so'n'so. They're a challenge.” I used to dread seeing those names. Now I'm much more able to look at that as, "This'll be a challenge. This'll be cool. I'm gonna figure out a way to make a connection."

Primary care physicians expressed greater confidence in specialty care involvement:

I was beginning to think more about my patients again, versus "I'll let the [hematology-oncology] doctor manage that." I can step up a bit more because I've been thinking about these disease processes more while I'm talking to students.

Teachers focused more on their patients as individuals as a result of teaching, sometimes using direct lessons or approaches from their work with students: “...because of the things we've taught our students about patient-centered interviewing...I like to think that I was doing that all along, but I had a lot of room for improvement."

Many physicians expressed greater joy or pleasure in practice:

I'd lost some of the wonder of the privilege of being a physician. Working with students has given that to me, realizing this person is sharing intimate details with me; it's a wonderful thing and it's a privilege.

\section{Trends in perceptions of skill improvement}

Among 24 faculty who commented on the impact of teaching students on their own clinical skills in two to three interviews, 22 described positive impact in all interviews. One described no impact of improved clinical skills in the first interview but positive impact in a subsequent interview. Another described no impact in the first interview and was unsure in a subsequent interview. Of seven faculty who discussed impact on their clinical skills in one interview, six described positive impact on their clinical skills and one described increased awareness of personal skill deficits.

One faculty member qualified the positive impact with concern about excessive time dissecting the clinical thought process: 
I found myself frustrated that I had spent so much time trying to dissect this pain complaint using a biomedical approach and not using my intuitive skills...knowing this thing was not the thing that was really on this poor woman's brain... These are important skills we're teaching, but students at some point are going to get to some advanced level beyond. But they can still go back and use these skills.

Comparisons were performed of themes and subthemes identified by primary care physicians and specialists. Both groups frequently described learning and relearning knowledge and skills, especially physical examination skills. Primary care physicians more frequently mentioned becoming more conscious of the process of care, focusing more on clinical reasoning, and becoming more self-confident. Specialists more frequently described becoming more patient-centered and improving interviewing and communication skills. There were no noticeable trends in comments by number of years teaching.

\section{Conceptual model}

The conceptual model developed to portray the relationships between themes is shown in Figure 1. In this model, the practice environment, with associated deterrents to maintenance and new learning, is expanded by the learning and re-learning process associated with basic bedside teaching. This expansion results in deconstruction of the clinician's practice style to one characterized by greater breadth and depth of skills and practice, increased focus on process of care, slowing down, and awareness of basic knowledge and skills that scaffold the more sophisticated, automated practice-in-action. This transition to a different practice style has a dynamic tension with the existing practice environment, resulting in reconstruction of the teacher's clinical practice to heightened self-awareness of the process of providing care. At the broadest level of outcomes, the practice environment is transformed to one characterized by perception of improved clinical skills and greater mindfulness: selfconfidence, focus on patients, and pleasure in practice. 
Figure 1: Conceptual model of the relationship between preclinical bedside teaching and impact on the teacher's clinical skills based on qualitative analyses of interviews completed between 2003 and 2007 with clinician-teachers in the University of Washington Colleges program.

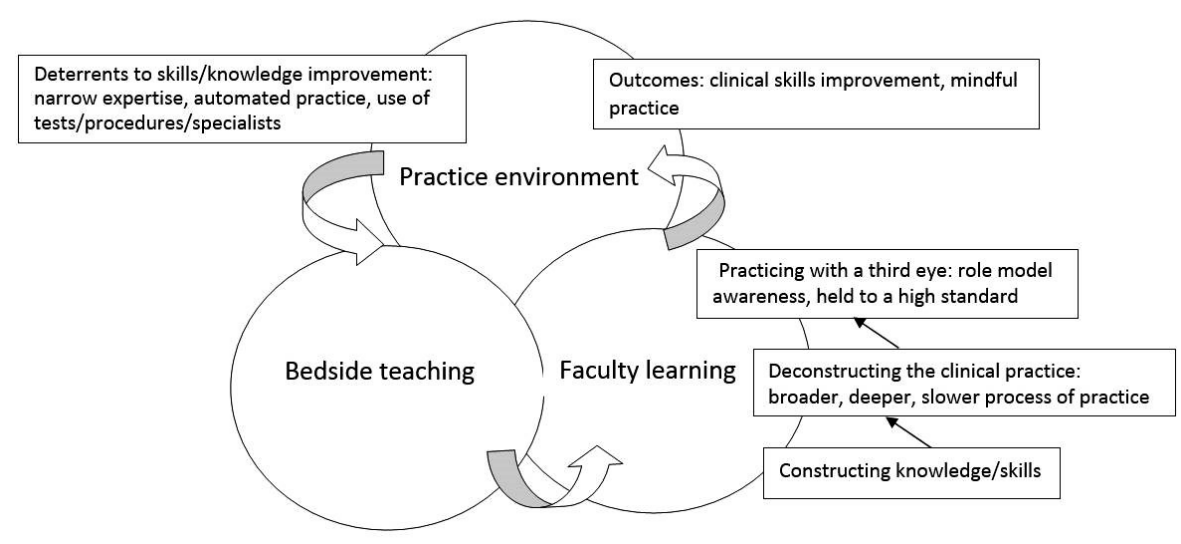

\section{DISCUSSION}

This study describes perceived effects of sustained bedside teaching on clinician-teachers' clinical skills. These data suggest that working with students at the bedside may profoundly and positively impact teachers' clinical skills in two ways. First, through identifying their own clinical skills deficiencies while preparing for or during teaching, clinician-teachers became conscious of the need to rectify these. As described in the literature, this selfidentification of deficiencies or areas of uncertainty concerning one's own knowledge and skills may have provided the motivation to move beyond a performance "plateau" and led to the commencement of reflective processes. ${ }^{14,15}$ Clinician-teachers who had come to rely primarily on history taking for diagnosis renewed their physical examination skills; increased use of physical examination in their own practices resulted in perceived positive impact on patient care.

Second, clinician-teachers developed a metacognitive approach to their skills and patient care-observing and reflecting on their skills and moving from unconscious to conscious, or tacit to explicit. Although tacit knowledge and pattern recognition are essential to clinical care, they may introduce habitual or automated behavior. However, clinical care cannot proceed at a constantly conscious level in which every observation and decision is subject to self-scrutiny. These data suggest the development of a state of practice comparable to the mindfulness described by Epstein and colleagues; ${ }^{25,26}$ clinicians function with heightened self-awareness and self-observation, use a beginner's mind, and act with presence. This increases clinicians' practice enjoyment and patient involvement. 
Clinician-teachers in this study described renewal and reinvigorated practice resulting from the process of bedside teaching, something central to their professional activities. Teaching led clinician-teachers to recognize areas of their "unconscious incompetence," whether newly identified or through disuse. ${ }^{27}$ Through being constantly engaged in bedside teaching, they held themselves accountable for continuously examining and renewing their skills. The result was perceived skill enhancement and, importantly, discovery or rediscovery of engagement in clinical practice through dissecting their practice, reflection, and reconstructing and experiencing their practice in a different, renewed manner.

This study suggests that teaching basic, foundational skills to medical students, compared with teaching at more advanced levels and in a fast-paced clinical setting with competing demands, may have a strong impact on physicians' clinical skills. This setting causes clinicians to relearn clinical skills in combination with deconstructing their clinical experiences to a basic nature and then rebuilding them to a more conscious and thoughtful state. We believe this teaching must be sustained and is best performed at the bedside in the context of real patients. This provides a dynamic tension between the tendency of physicians to automate clinical practice and the impetus, through clinical teaching, to re-examine and become conscious of their own clinical practice.

This study has several limitations. It studies physicians' skills in relationship to teaching within one educational approach that uses tutors with dedicated time for bedside teaching with small groups of students longitudinally. Increasingly, the importance of sustained curricular teaching and solid foundational clinical skills has been recognized. This qualitative study, appropriate for theory building, does not prove the influence of teaching on clinical skills. Physicians' perceptions of impact on their own clinical skills are precisely thatperceptions. Further, this was a study in one institutional setting. The longitudinal nature of the study with recurrent themes over time mitigates this limitation.

To further explore and evaluate our findings, quantitative and qualitative comparisons are needed of the impact on clinicians' clinical skills of teaching in other settings and circumstances, including the more usual combination of teaching while providing clinical care, ambulatory teaching, and teaching advanced medical students and residents. Teaching foundational clinical skills and perhaps clinical skills teaching at other levels may be the best form of continuing education for clinicians, and this could encourage more physicians to become involved in, learn from, and appreciate the value of foundational bedside teaching. 


\section{REFERENCES}

1. Ramsey PG, Carline JD, Inui TS, Larson EB, LoGerfo JP, Norcini JJ, Wenrich MD. Changes over time in the knowledge base of practicing internists. JAMA 1991;266:1103-1107.

2. Choudhry NK, Fletcher RH, Soumerai SB. Systematic review: the relationship between clinical experience and quality of health care. Ann Intern Med 2005; 142:260-273

3. Eva KW. The aging physician: changes in cognitive processing and their impact on medical practice. Acad Med 2002;77: S1-S6.

4. Vukanovic-Criley JM, Criley S, Warde CM, Boker JR, Guevara-Matheus L, Churchill WH, Nelson WP, Criley JM. Competency in cardiac examination skills in medical students, trainees, physicians, and faculty: a multicenter study. Arch Intern Med 2006;166:610-616.

5. Leigh TM, Young PR, Haley JV. Performances of family practice diplomats on successive mandatory recertification examinations. Acad Med 1993;68:912-919.

6. Collins J. Education techniques for lifelong learning: lifelong learning in the $21^{\text {st }}$ century and beyond. Radiographics 2009;29:613-622.

7. Manning PR, MD, DeBakey L. Continuing medical education: the paradigm is changing. J Contin Educ Health Prof 2001;21:46-54.

8. Accreditation Council for Continuing Medical Education. Annual Report 2009. Accessed at: http://www.accme.org

9. Davis D, O'Brien MA, Freemantle N, Wolf FM, Mazmanian P, Taylor-Vaisey A. Impact of formal continuing medical education: do conferences, workshops, rounds, and other traditional continuing education activities change physician behavior or health care outcomes? JAMA 1999;282:867-74.

10. Bloom BS. Effects of continuing medical education on improving physician clinical care and patient health: a review of systematic reviews. Int J Technol Assess Health Care.2005;21:380-5.

11. VJ Marsick and KE Watkins. Informal and Incidental Learning in the Workplace. London and New York: Rutledge Publishing, 1990.

12. Eraut, 2004, Informal learning in the workplace. Studies Cont Educ 2004;26:247-273.

13. Guest CB, Regehr G, Tiberius RG. The life long challenge of expertise. Med Educ 2001; 35:78-81.

14. Mamede S, Schmidt HG. The structure of reflective practice in medicine. Med Educ 2004;38:1302-1308.

15. DA Kolb. Experiential Learning: Experience as the Source of Learning and Development. Englewood Cliffs, N.J.: Prentice-Hall, 1984.

16. Sargeant J, Mann K, Sinclair D, Ferrier S, Muirhead P, van der Vleuten C, Metsemakers J. Learning in practice: experiences and perceptions of high-scoring physicians. Acad Med 2006;855:655-60. 
17. Ramani S, Orlander JD, Strunin L, Barber TW. Whither bedside teaching? A focusgroup study of clinical teachers. Acad Med 20031;78:384-90.

18. Ramani S. Twelve tips for excellent physical examination teaching. Med Teach 2008; 30: 851-856.

19. Hartley S, Macfarlane F, Gantley M, Murray E. Influence on general practitioners of teaching undergraduates: qualitative study of London general practitioner teachers. BMJ 1999;319:1168-1171.

20. Haffling A-C, Hakansson A, Hagander. Early patient contact in primary care: a new challenge. Med Educ 2001;35:901-908.

21. Goldstein EA, Maclaren CF, Smith S, Mengert TJ, Maestas RR, Foy HM, Wenrich MD, Ramsey PG. Promoting fundamental clinical skills: a competency-based college approach at the University of Washington. Acad Med 2005;80:423-33.

22. Whipple ME, Barlow CB, Smith S, Goldstein EA. Early introduction of clinical skills improves medical student comfort at the start of third-year clerkships. Acad Med 2006; 81:S40-3.

23. Jackson MB, Keen M, Wenrich MD, Schaad DC, Robins L, Goldstein EA. Impact of a pre-clinical clinical skills curriculum on student performance in third-year clerkships. J Gen Intern Med 2009; 24:929-33.

24. A Strauss, J Corbin. Basics of Qualitative Research: Techniques and Procedures for Developing Grounded Theory (2 ${ }^{\text {nd }}$ ed). Thousand Oaks, CA: Sage, 1998.

25. Epstein RM. Mindful practice. JAMA 1999;282:833-839.

26. Epstein RM, Siegel DJ, Silberman J.Self-monitoring in clinical practice: a challenge for medical educators. J Cont Educ in Health Prof 2008; 28:5-13.

27. T Swanwick. Understanding Medical Education: Evidence, Theory and Practice. NJ: Wiley-Blackwell, 2010. 


\section{Chapter 5}

From Cheerleader to Coach: The Developmental Progression of Bedside Teachers in Giving Feedback to Early Learners

MD Wenrich, MB Jackson, RR Maestas,

IAP Wolfhagen, AJJ Scherpbier

Published in:

Acad Med 2015; 90 (11 Supp): S81-S97 


\begin{abstract}
Background: Medical students learn clinical skills at the bedside from teaching clinicians, who often learn to teach by teaching. Little is known about the process of becoming an effective clinical teacher. Understanding how teaching skills and approaches change with experience may help tailor faculty development for new teachers. Focusing on giving feedback to early learners, the authors asked: What is the developmental progression of clinician-teachers as they learn to give clinical skills feedback to medical students?
\end{abstract}

Method: This qualitative study included longitudinal interviews with clinician-teachers over five years in a new clinical skills teaching program for preclinical medical students. Techniques derived from grounded theory were used for initial analyses. The current study focused on one theme identified in initial analyses: giving feedback to students. Transcript passages were organized by interview year, coded, and discussed in year clusters; thematic codes were compared and emergent codes developed.

Results: Themes related to giving feedback demonstrated a dyadic structure: characteristic of less experienced teachers versus characteristic of experienced teachers. Seven dominant dyadic themes emerged, including teacher as cheerleader versus coach, concern about student fragility versus understanding resilience, and focus on creating a safe environment versus challenging students within a safe environment.

Conclusions: With consistent teaching, clinical teachers demonstrated progress in giving feedback to students in multiple areas, including understanding students' developmental trajectory and needs, developing tools and strategies, and adopting a dynamic, challenging, inclusive team approach. Ongoing teaching opportunities with targeted faculty development may help improve clinician-teachers' feedback skills and approaches. 


\section{BACKGROUND}

An often-used aphorism about clinical teaching in medical education is "See one, do one, teach one." This phrase, most commonly about learning medical procedures but relevant to all clinical training, has implications for teachers and learners alike. Most clinical teachers learn to teach "on the job"; many begin during residency, with little training or oversight. ${ }^{1-4}$ Some learn or augment their skills through faculty development programs. ${ }^{5,6}$

A number of studies have advanced our understanding of clinical teaching; attributes of the excellent teacher have been identified and discussed. ${ }^{7-13}$ In a systematic review of characteristics of good clinical teachers, two-thirds were noncognitive, such as positive relationships with students and supportive learning environment, communication skills, and enthusiasm. ${ }^{7}$ Little is known about areas in which clinician-teachers develop teaching skills and approaches as they progress toward becoming effective clinical teachers. Elucidating what clinical teachers initially find challenging and where and how they change with experience may help tailor faculty development and identify new teaching models.

Through a longitudinal qualitative study, we examined on-the-job development of teachers as they began a new bedside clinical skills teaching program for preclinical students. Interviews were conducted with clinical teachers during the first five years of the Colleges program at the University of Washington School of Medicine to assess how they develop, change, and mature over time.

For the current study, we examined one teaching area that emerged as a dominant theme: giving feedback to students. Central to clinical teaching, feedback is necessary to optimal student skill development and refinement ${ }^{14-17}$ but is frequently avoided, underused, and imparted poorly. ${ }^{16,18,19}$ Most clinical teachers receive little or no instruction in giving feedback, ${ }^{16}$ though studies suggest that faculty development can positively advance feedback skills. ${ }^{20-22}$ Examination of how teachers develop expertise in giving feedback may provide insight regarding the trajectory for acquisition of this and other teaching skills. In this study of clinician-teachers working with medical students during their first intensive bedside clinical skills training, we asked the research question, How do clinician-teachers change in their teaching as they gain experience in giving clinical skills feedback to early learners at the bedside?

The conceptual framework through which we approached this work was pedagogical content knowledge ${ }^{23,24}$ which describes multiple forms of knowledge that contribute to excellent clinical teaching: knowledge of medicine, patients, and context as well as educational knowledge of pedagogy and learners, and case-based teaching scripts. This model recognizes 
and builds on the breadth and depth involved in mastery rather than considering either content or pedagogy alone as the core of teaching excellence. ${ }^{12}$

\section{METHODS}

\section{Description of teaching program}

The Colleges program, which began in 2003, provides clinical skills training to medical students throughout second year, along with mentoring throughout students' education. The program has been described. ${ }^{25-28}$ College faculty were clinician-teachers selected in a competitive process and represented many clinical specialties. All had experience teaching medical students and/or residents; however, prior to the Colleges program, preclerkship clinical skills teaching was provided in nonacademic, community preceptorships. Therefore, most participants in this study were new to teaching clinical skills to this student level, and none had done so on a long-term basis.

College faculty teach consistent groups of six students one morning a week throughout students' second year. Students perform complete history and physical examinations on inpatients, give oral case presentations to the mentor and peers, and complete write-ups. These sessions are supervised by the mentor and are followed by feedback for the student and teaching on the clinical case.

College faculty met monthly and frequently received faculty development in two-hour sessions on a variety of topics during those meetings. In the course of this study (2003-2007), two separate two-hour faculty development sessions focused on giving feedback to students. These consisted of guided group and small-group discussions about how to give feedback.

\section{Study design}

At the start of the Colleges program, investigators initiated a longitudinal qualitative study to assess how clinician-teachers approach teaching preclinical medical students. The study was conducted over five years (2003-2007), with three sets of one-on-one interviews. All 31 clinician-teachers agreed to participate; not all were available for all three interviews because of schedule conflicts.

Clinician-teachers were asked about teaching experiences, how their teaching changed over time, challenges and satisfaction, mentoring, and other areas. At the completion of interviews, three investigators undertook yearlong qualitative data analyses to identify key 
thematic codes for closer examination in subsequent analyses. The study described in this paper analyzes a key theme identified: giving feedback to students.

This research was granted exempt status in accordance with federal regulations under Category 2 by the University of Washington Human Subjects Division.

\section{Instruments and data collection}

Four investigators designed semistructured questions that were modified slightly each year to address emerging themes. During second interviews, many questions focused on mentoring roles. During the first and final interviews, more questions focused on clinical teaching. Examples include the following: How do you set priorities for a teaching session? How would you describe your approach to teaching students and what you feel they need to know? Has the way you give feedback changed or the amount of feedback that you give changed over time?

Five interviewers conducted interviews, which were audiotaped and transcribed without identifiers. Interviews averaged 30 minutes. Basic demographic data were collected, but because of the qualitative approach and limited participants, no efforts were made to correlate demographic data with individual transcript passages.

\section{Data analysis}

For the initial study, three investigators (including M.D.W. and M.B.J.) reviewed all transcripts from all years and developed codes using constant comparison and coding techniques derived from grounded theory. ${ }^{28}$ The investigators first independently developed initial coding structures based on five transcripts and then met to discuss and agree on a common coding approach and initial code definitions. Over the subsequent year, investigators coded all transcripts, meeting in pairs to compare and resolve discrepancies and agree on new codes. Codes were then organized into larger, related clusters. Data organization was performed using Atlas Ti software. Giving feedback to students was one of the emergent key codes.

For the current study, three investigators (M.D.W., M.B.J., R.R.M.) reviewed all passages for the code "giving feedback to students" and independently developed thematic codes. Passages were organized by interview year and reviewed in order, from earliest to latest (i.e., Year 1 first, then Year 3, and then Year 5), with themes subsequently identified and clustered by year. All passages were discussed in year clusters, and thematic codes were compared among three investigators. This permitted assessment of the study participants" "maturation" over the five years in their perspectives. 
Rather than restricting codes to limited words or phrases, investigators allowed significant flexibility in using longer descriptive phrases, incorporating all relevant descriptors, and did not limit the number of codes. This provided a phenomenological approach in which investigators responded to the experience in the words rather than strict isolation of codes as symbolic placeholders. Examples of thematic codes are "encouragement/supportive," "tailors feedback to student preference," "a lot of praise, a little criticism," "gives specific feedback," and "able to give repetitive critical feedback." Discrepancies were discussed and resolved.

After initial coding, investigators independently reviewed thematic codes by year with associated passages and developed emergent themes for each year. The investigators compared themes and determined the most relevant and salient. For each emergent theme, investigators re-reviewed transcripts to ensure theme veracity to the data. The investigators then examined themes for longitudinal trends.

\section{Validation of themes}

To ascertain theme validity, two focus groups were held in 2014. The first was held with five participants in the original interviews. The second was with five clinician-teachers who had taught in the Colleges for less than two years. All respondents agreed to participate.

Participants were asked to review the themes and discussed which were meaningful to them and which were not, and to identify whether the data resonated overall. One investigator (M.B.J.) led the focus groups, and two investigators (M.D.W., R.R.M.) took detailed notes.

In general, the themes resonated with both more and less experienced teachers. Several in both focus groups suggested slight wording changes. Some specific comments from focus group participants are included in Results.

\section{RESULTS}

Of 31 participants, 29 were interviewed two or three times, and 2 were interviewed once, for a total of 82 interviews. Fourteen participants were men and 17 were women. Twenty practiced primary care, and 11 practiced other specialties (e.g., pediatric subspecialty, psychiatry, obstetrics-gynecology). ${ }^{28}$ Thirteen had taught 10 or fewer years, and 18 had taught more than 10 years.

Themes were organized dyadically into "More Characteristic of Less Experienced Teachers" and "More Characteristic of Experienced Teachers." Seven dyadic themes were 
identified with contrasting descriptors (Table 1). (The number and year after each quote below represent the physician identification and the interview year among the three progressive interviews performed in 2003, 2004, and 2007 with the same group of teachers.)

Table 1: Themes related to giving feedback to early clinical skills learners: Characteristics of less experienced compared with more experienced bedside teachers

\begin{tabular}{|c|c|}
\hline LESS EXPERIENCED TEACHERS & MORE EXPERIENCED TEACHERS \\
\hline $\begin{array}{l}\text { Teacher as cheerleader } \\
\text { Focus on positive, minimize negative } \\
\text { Provide general, non-specific feedback }\end{array}$ & $\begin{array}{l}\text { Teacher as coach } \\
\text { Provide honest, transparent feedback } \\
\text { Specific, directive, targeted feedback }\end{array}$ \\
\hline $\begin{array}{l}\text { Passive teacher role } \\
\text { Follow student lead: "Tell me what you need" } \\
\text { Remain in background at bedside } \\
\text { Give postponed feedback }\end{array}$ & $\begin{array}{l}\text { Calibrated teacher role } \\
\text { Push student to reflective adult learner } \\
\text { role } \\
\text { Selectively exercise active role at bedside } \\
\text { Balance immediate/delayed feedback } \\
\end{array}$ \\
\hline $\begin{array}{l}\text { Concern about students' fragility } \\
\text { Worry about impact of negative feedback }\end{array}$ & $\begin{array}{l}\text { Understand students' resilience } \\
\text { Know that students want specific, critical } \\
\text { feedback }\end{array}$ \\
\hline $\begin{array}{l}\text { Create a safe environment } \\
\text { Deter student discomfort }\end{array}$ & $\begin{array}{l}\text { Create a challenging but safe } \\
\text { environment } \\
\text { Expect a response: "You show me," "It's } \\
\text { okay not to know," and "We're here to } \\
\text { develop everyone's skills" }\end{array}$ \\
\hline $\begin{array}{l}\text { Limited goals and strategies } \\
\text { Don't know what works in giving feedback } \\
\text { Use trial and error: "Whatever works" } \\
\text { Limited skill and comfort addressing behaviors and } \\
\text { personality traits (e.g. student anxiety) that limit skill } \\
\text { building }\end{array}$ & $\begin{array}{l}\text { Strategic and goal-oriented } \\
\text { Have strategies and language for giving } \\
\text { feedback } \\
\text { Have goals and expectations: "This } \\
\text { works" } \\
\text { Address and name students' limiting } \\
\text { behaviors and personality traits (e.g. } \\
\text { student anxiety); offer techniques for skill } \\
\text { building }\end{array}$ \\
\hline $\begin{array}{l}\text { Oriented toward students' current needs } \\
\text { Teach without a long-range plan }\end{array}$ & $\begin{array}{l}\text { Oriented toward students' } \\
\text { developmental trajectory } \\
\text { Know what skills students should have at } \\
\text { different stages of development }\end{array}$ \\
\hline $\begin{array}{l}\text { Minimal use of teams } \\
\text { Private one-on-one feedback from teacher }\end{array}$ & $\begin{array}{l}\text { Foster environment of team feedback } \\
\text { Utilize peers and patients in giving } \\
\text { feedback }\end{array}$ \\
\hline
\end{tabular}




\section{Theme 1: Teacher as cheerleader/teacher as coach}

Less experienced teachers described focusing on positive feedback and minimizing negative feedback:

I tend to be a bit of a cheerleader. Try and emphasize what they're doing well.... "All this will come with time. Have faith, you're doing fine.” (MD 27, Year 1)

More experienced teachers described providing honest, transparent feedback:

[Last year] I felt I had to be everybody's friend and be positive and a cheerleader. This time, I lost that feeling. I thought to myself, I don't care if they consider me a friend. I think they'll grow and they'll respect me regardless if I get them to a better place. (MD 45, Year 2)

Less experienced teachers provided feedback in very general terms:

I like to give people pats on the back and say, “Oh, you're doing a great job.” (MD 45, Year 1)

Those with more experience described being more specific, directive, and targeted:

You're off track here. You need to try something else. Maybe you should try this. (MD 66, Year 3)

\section{Theme 2: Passive teacher role/calibrated teacher role}

Less experienced teachers described a relatively passive role at the bedside compared with the more active, dynamic involvement of experienced teachers. Less experienced teachers tended to follow students' lead. In bedside sessions, they described postponing feedback so as not to interrupt:

I tend to be a fly on the wall. Afterwards, I'll talk about things they could have done better. (MD 45, Year 1) 
Some described a tension between being passive versus active at the bedside:

On the one hand you want to sit back and see what happens when they ask their questions without too much input. That's hard to sit back and let it spin like that, especially when you see things going inefficiently. (MD 67, Year 1)

In contrast, more experienced teachers played a dynamic and selectively active role in giving feedback at the bedside, balancing immediate and delayed feedback:

I try to let them interview a patient and get comfortable and I try to not go in for the history.... When I go in to watch the physical, I often sit at the bedside with them and talk it through. Watch them do it and give 'em feedback and then watch them do it and then give them feedback. (MD 24, Year 3)

In another example:

I interject and show them right there. Or, I'll ask a question. If they're bogged down and dragging, I'll try and pick it up. Or, I'll ask them something that's important. (MD 57, Year 3)

\section{Theme 3: Concern about student fragility/understand students' resilience}

Less experienced teachers expressed concern that critical feedback would negatively impact students' egos or impede progress:

It's the struggle of how to teach in a way that doesn't damage their self-esteem, their ego. Being able to say, "No, you didn't do that right" or "You need to improve" in a way that doesn't make them feel like they're failing... (MD 36, Year 1)

Some worried about long-term impact:

[O]ne little negative feedback or so-called constructive comment really can be painful. You start questioning your ability to do this tough job. (MD 56, Year 2) 
More experienced teachers expressed understanding that students want specific feedback:

I've learned that students don't take it personally, they don't get upset. They like feedback. (MD 47, Year 2)

Another said:

I've sent [the write-up] back to them and said, "You have to rewrite this. This is not appropriate." And "This is totally sloppy. If you do this next year, you'd fail." Then they'd come back and do it again and do it properly. I think they've been receptive to that. (MD 45, Year 3)

\section{Theme 4: Create a safe environment/create a challenging but safe environment}

Less experienced teachers did not want to put students on the spot and tried to deter student discomfort. They described a protective role:

There's times when we need to not stymie people's morale and rein them in. There's almost a positive parental quality with the mentors.... (MD 88, Year 1)

Another said:

My strategy is to say, "This is a safe environment and I expect you guys are all going to make lots of mistakes." When they do make a mistake, I say, "That's a mistake. Right? But we're in a safe environment." (MD 69, Year 1)

In contrast, more experienced teachers expected students to demonstrate skills and knowledge, while supporting small-group safety. They tried to contextualize risk taking during this formative period:

All the students were going to be expected to give feedback to each other and to me and it was going to be a two-way street. That was what I expected and next year was going to be high stakes. And this was a safe environment where people could give feedback, and why not get it now rather than crash and burn next year? (MD 56, Year 2) 


\section{Theme 5: Limited goals and strategies/strategic and goal oriented}

Less experienced teachers expressed or demonstrated lack of understanding of what works in giving feedback. Lack of available techniques could frustrate them:

I've got a couple of students who keep making the same mistakes over and over.... I need to figure out different ways of providing feedback so they hear it. (MD 27, Year 2)

More experienced teachers described strategies and language for giving feedback:

[J]ust getting it out in the open, learning a language to give feedback that is less hot, has made it much more comfortable. (MD 48, Year 3)

Experienced teachers were more explicit in articulating clear goals and expectations:

Being explicit about expectations. I tell them they should not use notes, they should memorize.... And I say, "This is how this translates. You have to look back and forth to your notes and that interrupts your interview and makes you go slower than everyone else." (MD 75, Year 2)

Less experienced teachers described limited skill and comfort in addressing behaviors and personality traits that impede students' skill building, such as anxiety:

If somebody isn't natural in building rapport, it's difficult to teach that. You can't teach it in a didactic manner, so it seems like modeling sometimes helps and then giving feedback about what they did and how they can change.... (MD 36, Year 1)

More experienced teachers addressed and named limiting behaviors and traits and provided approaches that gave a path forward. For example:

She was really nervous. She blasted through ... and the patient said, "You'd make a good lawyer." All her questions were right, she got through everything perfectly and I could say, "You didn't give enough time for the patient to answer the questions and that's why 
he said what he said. There are techniques you might use to help that." And the next time, she was way more relaxed. (MD 75, Year 2)

\section{Theme 6: Oriented toward students' current needs/oriented toward students' developmental trajectory}

Less experienced teachers went into teaching days without a plan:

I basically ask them every time, "What are you focusing in on today? What do you want me to watch? Is there anything specific you want feedback on today?” (MD 33, Year 1)

More experienced teachers knew what skills students should have at each developmental stage and tailored teaching accordingly:

I can now gauge, are they meeting what I generally expect at the end of winter quarter? Some people are beyond that and I say, "You are doing everything I expect at end of winter quarter. Now I want you to start focusing on this. These are things I see as your strengths. I'm gonna keep giving feedback on interviewing and physical exam, but you're ready. You're asking questions to rule in and rule out different hypotheses. It's awesome. You need to turn that into a definite plan." (MD 75, Year 3)

\section{Theme 7: Minimal use of teams/fosters environment of team feedback}

Less experienced teachers described providing feedback in private:

[W]e had a meeting for about half an hour and we were developing strategies about how he could do more of the physical exam, what it would take. (MD 24, Year 1)

More experienced teachers used peer students in coaching and giving feedback:

I gave them the option to observe each other and provide feedback and provided them an outline they could use to give that feedback ... they were very insightful. It was the type of feedback you can't give as the mentor, that a peer can give. (MD 12, Year 3) 
More experienced teachers also used patients as feedback providers:

Always I tell the patient, "Mark here is going to present to the other students what he found [out] about you. I want you to make sure you correct him if he's wrong." (MD 54, Year 2)

\section{Validation results}

Our member check focus groups validated the dyadic themes that emerged in this study and provided new analytic insights. Both more and less experienced clinician-teachers agreed with and affirmed the themes in Table 1. Both groups observed, however, that giving feedback at any level of experience is fluid. For example, intentional use of "less experienced skills" may be more appropriate for some students or some settings than more "expert skills." More experienced teachers noted that they use variable skills based on different factors. One said, "You can be a master teacher and have a novice day or have a tough group of students." Another noted that a teacher can deliberately use skills more characteristic of less experienced teachers earlier in the year and move to more nuanced, "expert" skills as students progressed and were ready for more challenge. They observed that less experienced teachers tend to view students as homogeneous groups, whereas more experienced teachers see students' individual variations and adapt feedback to the student's level — confirming the theme of "addressing students' current needs" versus "oriented to students' developmental trajectory."

Less experienced focus group members discussed a "teacher developmental trajectory," comparable to the "student developmental trajectory." One noted that she is still relearning her own clinical skills while teaching them and this may limit her ability to identify problems or weaknesses and provide feedback. Several discussed that as they develop experience, they perceive teachers develop pattern recognition related to student problems or challenges, what requires feedback, and how to give it. One said, "I had two students who struggled this year and I'm grateful - now I have two major diagnoses. I can identify those problems in the future." 


\section{DISCUSSION}

This study used longitudinal interviews over five years with clinician-teachers working in a new clinical skills teaching program to examine how teaching approaches and skills changed with increasing experience. We focused on one aspect of teaching that emerged in earlier analyses - giving feedback to early learners - as a lens through which to study clinical teachers' progression. Our study identified that the skills of clinician-teachers who teach consistently at the bedside progress rapidly in a number of areas, including knowledge of learners, development of approaches and strategies, and focus on long-term, developmental goals for students rather than limited, short-term, general feedback.

Figure 1 portrays the areas in which we saw discrepancies between less experienced and more experienced teachers and progression with time. Consistent with the concept of pedagogical content knowledge, we saw that the needed knowledge that is relevant to teaching was complex and multifactorial. Teachers learned pedagogical strategies and developed an understanding of students' typical developmental trajectory as well as variations in individual students. They adopted a language for giving feedback. Their concern about student fragility advanced to awareness that most students are resilient and want constructive feedback rather than neutral or positive generalities. Their initial awareness of wanting to create a "safe space" for students evolved to a focus on learning environments that are simultaneously safe and challenging. The nature of challenge itself changed from a threatening phrase to one that is richly nuanced by dynamic and calibrated engagement, setting expectations and pushing students to a new place, all the while maintaining a safe and supportive learning environment. They learned to use both patients and peer students as co-coaches for learners. During the five-year period, faculty received two 2-hour faculty development sessions on giving feedback, which may have augmented their skill development in giving feedback. 


\section{Figure 1: Conceptual model of progression of skills at giving feedback at the bedside}

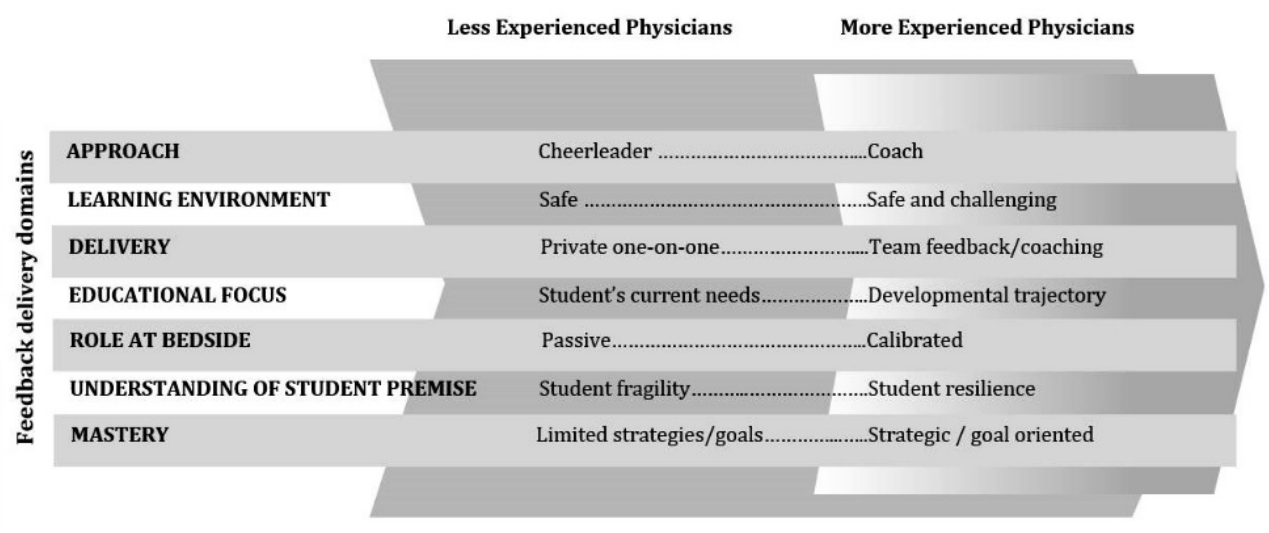

Our member check focus groups validated the themes and offered new analytic insights. Just as clinicians develop pattern recognition through an understanding of patient classification and experience with specific patients in different contexts, so do teachers develop pattern recognition of students, both the normal developmental trajectory and variations from the norm, along with associated strategies for addressing normal and variants. Irby ${ }^{12}$ elegantly describes this phenomenon and the teaching scripts resulting from the integration of the many forms of knowledge relevant to teaching: medicine, patients, contexts, pedagogy, and learners. In addition, recognition of a "teacher developmental trajectory" in this study speaks to learning to teach as a process with stages and transitions.

Like learning the art and science of medicine, learning to teach is not a simple process dependent on content or pedagogy alone. Our study suggests that teacher development in giving feedback requires learning a language for giving feedback; developing strategies for different circumstances, students, and needs; and understanding and incorporating students' developmental trajectory and learning variations in individual students from that trajectory and associated strategies that help guide and tailor feedback. All these intersect with and build on medical knowledge and clinical skills, components frequently considered the foundation of clinical teaching. An outcome - which itself becomes part of the "package" of the experienced teacher-is development of an emotional component, teacher selfconfidence, that permits teachers to trust their abilities and instincts. 
These data suggest strategies for helping teachers advance in providing feedback to students and in becoming learners themselves in pursuit of teaching mastery. The "workplace environment" is a rich laboratory for learning to teach and may be advanced as such by recognizing and focusing on the areas in which teacher progress must be made, as laid out in this paper. In addition, more experienced teachers may play a role in helping less experienced teachers by joining them as they teach to provide feedback and advice on the observed teachers' skills. ${ }^{4}$ Alternately, less experienced teachers can join the more experienced teachers, observe their teaching and feedback approaches, and reflect about their approaches and observations immediately after each session.

Our data also suggest that programs like the Colleges that situate teachers in longitudinal clinical settings with students may have advantages for students and for teachers themselves: sustained, longitudinal teaching appears to lead to clear progress and self-confidence in skills at giving feedback. Occasional or intermittent teaching may not have the same advantages. We suggest that sustained teaching of consistent groups of students within a dedicated teaching program permits faculty to progressively increase their skills at giving feedback and other clinical teaching skills. Faculty development to help teachers obtain skills in giving feedback and other skills is likely to augment and enrich this "on the job" learning. Isolated and/or intermittent teaching is unlikely to have the same impact, and the presence of a community of peer clinician-teachers with whom faculty development and common or similar experiences are shared, as occurs in the Colleges program, is likely to add to the impact.

This study has several limitations. First, new clinical teachers are sometimes relearning basic bedside clinical skills themselves after functioning in advanced or specialized practices. As skills improve, so will their feedback and overall teaching skills. Shulman's concept ${ }^{23,24}$ recognizes the high value of content and skill in the multifactorial rubric of effective teaching. ${ }^{12,20,21}$ Second, during clinical clerkships, students, residents, and attending physicians combine caring for patients with teaching students. In the Colleges, clinical teachers focus on teaching early learners, which might change their teaching. Third, we did not consider in our analyses the role that faculty development may have played in teachers' skill development - whether within or outside the College faculty setting. It is possible that 
the role of faculty development was significant. Fourth, these interviews were conducted between 2003 and 2007 and may be more reflective of teachers at that time; data from the member validation, however, suggest that the data and insights remain fresh. Finally, our study examined teaching with preclinical learners at the bedside. Our findings may not generalize to more advanced learners in other settings.

Despite these limitations, our data suggest that learning to give feedback to early learners in the development of clinical skills involves multiple areas for attention and that sustained teaching in the workplace is an excellent environment for advancing teaching skills. The authors believe that this "on the job," sustained (as opposed to episodic or occasional) experience will be best supported by ongoing faculty development related to giving feedback. Targeted faculty development from experienced teachers who recognize the areas for attention identified in this paper may help new teachers to advance their skills efficiently and effectively. 


\section{REFERENCES}

1. Wilkerson L, Irby DM. Strategies for improving teaching practices: A comprehensive approach to faculty development. Acad Med 1998;73:387-396.

2. MacDougall J, Drummond MJ. The development of medical teachers: An enquiry into the learning histories of 10 experienced medical teachers. Med Educ 2005;39:1213-1220.

3. Ramani S, Leinster S. AMEE guide no. 34: Teaching in the clinical environment. Med Teach 2008;30:347-364.

4. Cook V. Mapping the work-placed learning of novice teachers: Charting some rich terrain. Med Teach 2009;31:e608-e614.

5. Johansson J, Skeff K, Stratos G. Clinical teaching improvement: The transportability of the Stanford Faculty Development Program. Med Teach 2009;31:e377-e382.

6. Skeff KM, Stratos GA, Mygdal W, et al. Faculty development. A resource for clinical teachers. J Gen Intern Med 1997;12(suppl 2):S56-S63.

7. Sutkin G, Wagner E, Harris I, Schiffer R. What makes a good clinical teacher in medicine? A review of the literature. Acad Med 2008;83:452-466.

8. Irby DM. Clinical teacher effectiveness in medicine. J Med Educ 1978;53:808-815.

9. Irby DM, Ramsey PG, Gillmore GM, Schaad D. Characteristics of effective clinical teachers of ambulatory care medicine. Acad Med 1991;66:54-55.

10. Irby DM. Three exemplary models of case-based teaching. Acad Med 1994;69:947-953.

11. Irby DM. What clinical teachers in medicine need to know. Acad Med 1994;69:333-342.

12. Irby DM. Excellence in clinical teaching: Knowledge transformation and development required. Med Educ 2014;48:776-784.

13. Pinsky LE, Monson D, Irby DM. How excellent teachers are made: Reflecting on success to improve teaching. Adv Health Sci Educ Theory Pract 1998;3:207-215.

14. Wolverton S, Bosworth M. A survey of student perceptions of effective teaching behaviors. Fam Med 1985;17:106-108.

15. Ramani S, Krackov SK. Twelve tips for giving feedback effectively in the clinical environment. Med Teach 2012;34:787-791.

16. Cantillon P, Sargeant J. Giving feedback in clinical settings. BMJ 2008;337:1292-1294.

17. Watling CJ. Unfulfilled promise, untapped potential: Feedback at the crossroads. Med Teach 2014;36:692-697. 
18. Gil DH, Heins M, Jones PB. Perceptions of medical school members and students on clinical clerkship feedback. J Med Educ 1984;59:856-864.

19. Ende J. Feedback in clinical medical education. JAMA. 1983;250:777-781

20. Norcini J, Burch V. Workplace-based assessment as an educational tool: AMEE guide no. 31. Med Teach 2007;29:855-871.

21. Foster K, Laurent R. How we make good doctors into good teachers: A short course to support busy clinicians to improve their teaching skills. Med Teach 2013;35:4-7.

22. Burgess A, Mellis C. Feedback and assessment for clinical placements: Achieving the right balance. Adv Med Educ Pract 2015;6:373-381.

23. Shulman L. Those who understand: Knowledge growth in teaching. Educ Res 1986;15:414.

24. Shulman L. Knowledge and teaching: Foundations of the new reform. Harv Educ Rev $1987 ; 57: 1-22$.

25. Goldstein EA, Maclaren CF, Smith S, et al. Promoting fundamental clinical skills: A competency-based college approach at the University of Washington. Acad Med 2005;80:423-433.

26. Jackson MB, Keen M, Wenrich MD, Schaad DC, Robins L, Goldstein EA. Impact of a pre-clinical clinical skills curriculum on student performance in third-year clerkships. $J$ Gen Intern Med 2009;24:929-933.

27. Whipple ME, Barlow CB, Smith S, Goldstein EA. Early introduction of clinical skills improves medical student comfort at the start of third-year clerkships. Acad Med 2006;81(10 suppl):S40-S43.

28. Wenrich MD, Jackson MB, Ajam KS, Wolfhagen IH, Ramsey PG, Scherpbier AJ. Teachers as learners: The effect of bedside teaching on the clinical skills of clinicianteachers. Acad Med 2011;86:846-852. 

CHAPTER 6

DISCUSSION 
As outlined in the literature review in Chapter One, while the use of the bedside for teaching clinical skills has declined over the years, increased attention has focused on the value of bedside teaching in providing foundational clinical skills training prior to clerkships. The need for early patient experience and better clinical preparation of medical students prior to clerkships has long been described from several perspectives, including those of teachers and students themselves. ${ }^{1-3}$ Yet to date, there has been little attention to developing new approaches to introducing students to clinical skills and to evaluating the benefits and challenges of the various existing approaches.

In addition, to be effective, students AND teachers must perceive benefits to the clinical teaching modalities being used. Little attention has focused on either of these areas in relationship to clinical teaching. Some attention has focused on what defines a good clinical teacher but few studies have examined the benefit clinical teachers themselves perceive in the teaching experience.

Guided bedside teaching has been used in a variety of North American medical schools for the past 15 years as a structured, small-group approach to training preclinical medical students in clinical skills while familiarizing them with team-based medicine and the real world of patients. This is typically performed within a learning community model. ${ }^{4-6}$

Several studies have shown positive outcomes of guided bedside teaching for student performance and comfort in clerkships, including better performance on internal medicine clerkships and technical communications in clerkships and increased student comfort in key clinical skills areas during the start of clerkships. ${ }^{7-8}$

This thesis examined the functions and roles of guided bedside teaching for early learners and their teachers. We asked, how and to what extent does guided bedside teaching prepare preclinical medical students in the clinical skills they will need as they move into clerkships? Does guided bedside teaching have advantages over other teaching approaches for imparting clinical skills? And what are the advantages and consequences for clinical teachers involved in guided bedside teaching in terms of their own roles as teachers and physicians? 


\section{Benefits for students and comparisons to other early teaching approaches}

To assess the functions and roles of guided bedside teaching for students, we performed two sets of comparisons: 1) a comparison of students, guided bedside teachers and clerkship directors in their perceptions of needed skills in preparation for clerkships; and 2) a comparison of guided bedside teaching with other commonly used preclinical introductory approaches to clinical skills development. ${ }^{9-10}$

Overall, these studies elucidated that guided bedside teaching is a highly effective teaching modality for preclinical learners in basic clinical skills training in anticipation of clerkships. It prepares learners well in the basic clinical skills of history-taking, performing a physical examination, communication with patients, performing an oral case presentation, introductory critical reasoning, and completing a write-up. It provides a combination of high curricular structure, as evidenced by the use of benchmarks as guidelines for students and their teachers, and some independence for students at the bedside so that they can begin to develop self-confidence and the first steps of mature decision-making.

In the first set of comparisons, however, the lack of congruence between the perceptions of students early in clerkship training, guided bedside teachers and clerkship directors suggests differing expectations for clinical skills training in preparation for clerkships, with students expecting preparation in advanced skills such as focused examinations and oral case presentations compared with clerkship directors and guided bedside teachers. ${ }^{9}$ Whether guided bedside teaching or any other teaching modality can meet the expectations of students in training them in all the skills they feel they should master in anticipation of clerkships is not fully answered by these studies. And in fact, meeting the expectations of students may be an impossible undertaking; students are likely to always feel some "shock of practice" no matter what level of preparation they have. ${ }^{2}$ But these studies suggest some level of continued disconnection between the preclinical and clinical environments based on perceived insufficient clinical training in preparation for clerkships. Students perceived themselves as capable of learning more advanced clinical skills prior to the start of clerkships and that they would benefit from this. Both guided bedside teachers and clerkship directors, like students themselves, had high expectations for basic science knowledge. However, the divergence 
between guided bedside teacher and clerkship directors in other areas is notable: guided bedside teachers had higher expectations than clerkship directors for both basic clinical skills and for several more advanced skills, including focused history and focused physical exam.

Still to be determined in the new curriculum is whether there can be good alignment between the understanding and expectations of clinical skills teachers in the preclinical phase with the understanding and expectations of clerkship directors concerning what skills students should have in preparation for clerkships. This alignment of expectations among teachers at different points in training for preparation in clinical competencies is an important component of a truly integrated curriculum and must be intentional and proactive. Students, too, must be prepared in an integrated manner by both sets of faculty for what is expected of them as they begin clerkships in terms of specific skills and skill levels. This could be accomplished through common development of learning objectives between guided bedside teachers and clerkship directors for the start of clerkships.

In the second set of comparisons of guided bedside teaching with other early clinical experiences, comparison categories were developed based on open-ended responses from students in an initial questionnaire concerning how guided bedside teaching and preceptorships differ. ${ }^{10}$ These categories included clinical skills training but also other areas relevant to clinical training, including developing comfort in clinical settings, learning about the life of a physician, learning to be part of a team, and making decisions about career/specialty.

The two years of survey data we obtained suggest that guided bedside teaching offered systematic and comprehensive training in the development of basic clinical skills. In comparison, preceptorships offered a realistic and more practical introduction to what clinical medicine looks like in the real world and the world awaiting students in the future. One form of preceptorship, a concentrated immersion experience in which students were placed in rural settings with a physician preceptor for four weeks and lived in that community, received the highest ratings for understanding the life of a physician and what community practice is like. Guided bedside teaching led to the greatest comfort with clinical skills and with clinical 
settings. Guided bedside teaching and both preceptorships offer unique advantages and complement one another in what they offer students.

These data suggest that the optimal preparation for clerkships in order to maximize both clinical skills training and comfort with and understanding of the life and practice of a physician may be a combination of types of clinical teaching experiences during the preclinical phase. This could combine the more structured guided bedside teaching approach in inpatient settings with time in a physician's outpatient offices. And in fact, the University of Washington School of Medicine's subsequent development of a modified clinical curriculum as the result of a curriculum reform initiated in 2015 is adopting this approach. Students experience a combination of guided bedside teaching in inpatient settings, clinical skills workshops for half a day twice a month, and outpatient clinical exposure on a twicemonthly basis in the office of a primary care physician. In addition, students receive a 2-3 week clinical immersion at the start of their medical school education that prepares them in basic clinical skills and many students continue to choose the option of a summer four-week clinical immersion, the Rural/Underserved Opportunities Program.

The first of the three surveys for the examination of the benefits of early patient contact asked students what was most important about the Colleges' guided bedside teaching approach. Interestingly, the most frequently cited benefit was patient contact, followed by the mentor relationship with a faculty member and working in a team/small group setting. The development of specific skills areas was cited slightly less often. This suggests that the obvious rewards for students of guided bedside teaching, like other early patient experiences, may be the patient exposure itself-whether due to the break from classroom learning, the integration of theory with practice, ${ }^{11}$ the development of empathy, ${ }^{12-13}$ or the experience of developing intimacy with the direct exposure to patients during the predominantly classroom period of their education. ${ }^{14}$

\section{Benefits of guided bedside teaching for and impact on guided bedside teachers}

Our studies also examined the roles and benefits of guided bedside teaching from the vantage point of the teachers themselves. ${ }^{15-16}$ While a number of historical studies, particularly by 
Irby and colleagues, have examined the attributes of an excellent clinical teacher, few studies have examined how teachers change as a result of their teaching. ${ }^{17-21}$ This is partly because many academic faculty teach sporadically - either as attending physicians for concentrated periods of time or occasionally as part of a specific, time-limited class. The Colleges program, with its sustained guided bedside teaching approach, uniquely offers a longitudinal teaching setting throughout the year and over a number of years, with little change in the program itself. In these studies, we asked, what are the advantages and consequences for clinical teachers involved in guided bedside teaching in terms of their own roles as teachers and physicians?

Our database for these examinations was a set of longitudinal interviews of the College faculty about their teaching experiences. Guided bedside teachers were interviewed three times over the first five years of the program starting at the end of the first year of the program. These interviews provided valuable insight into how they progressed and matured as teachers as a result of sustained teaching.

The interviews of the 31 faculty were undertaken in 2003 to understand how clinicianteachers approach teaching and how they perceive their skills and teaching change over time. A subsequent year-long comprehensive period of qualitative analyses of the interviews used components of grounded theory to isolate key thematic areas with associated codes.

For the first study of faculty, we isolated the emergent code "mentor clinical skills" that refers to the influence of teaching on physicians' own clinical skills and we reviewed relevant passages for themes. ${ }^{15}$ Of the six themes that emerged in analyses, one related to deterrents to the faculty members' skills improvement prior to participating as teachers in guided bedside teaching. The other themes related to the ways in which the clinicians improved through involvement as teachers in guided bedside teaching-through direct skills development as a result of relearning clinical skills in order to teach and through demonstrations to students, but more frequently, through the metacognition that began to permeate their own clinical work with patients as a result of teaching. Teachers became more self-aware of themselves as clinicians working with patients, reflectively observing their own skills and moving back to a more basic level that they used in working with students. Perhaps 
the term that comes to mind most directly is "mindfulness"-clinicians described the way they began to see their patients and their own skills through an additional lens, whether through their students' eyes or their own, increasing their awareness and perspectives. The outcomes they described were greater self-confidence and comfort with challenges, a more patient-centered approach, and greater practice enjoyment. Faculty again began to relish caring for patients, enjoying the process itself rather than operating in a relatively automated manner.

The results from this study suggest that teaching clinical skills to medical students at a basic, foundational level "forced" physicians to confront their own clinical deficiencies, often the product of the passage of time since training and sustained participation in limited practices. They reconstructed their clinical skills through a combination of refining and relearning knowledge and skills, learning from peers, and through the very process of teaching. This self-awareness as teachers extended into their clinical practices, and ultimately led to greater enjoyment, self-confidence and patient-centeredness.

This megacognitive process may be a unique result of faculty who are required to teach in a very personal, continuous setting like guided bedside teaching. Teachers in such settings cannot limit their teaching to isolated periods as occurs in many teaching settings, but rather must be prepared to teach their same small group of students on a weekly basis. There is no "out" introduced by competing demands, other responsibilities, and limited timeframes. The deconstruction and subsequent reconstruction of one's skills provides a unique advantage to teachers independent of, yet closely tied to, the rewards of teaching students. A recent survey of faculty teachers across five U.S. medical schools confirms the perception that their own clinical skills improve as a result of participating in learning community settings. ${ }^{22}$

The second study of guided bedside teachers examined the impact of teaching on their teaching skills. ${ }^{16}$ Again, using the initial set of analyses performed of the interviews over five years, we isolated one of the predominant themes, giving feedback to students. We examined that theme in a detailed approach using elements of grounded theory but also incorporating elements of phenomenology in order to delve into the lived experience of the teachers. Our assumption was that identifying any changes that result over time for this key area of teaching 
could potentially be extrapolated to other teaching skill areas. We augmented the analyses with two focus groups performed in 2014 that permitted us to validate our thematic findings and also to examine and analyze newly emerging observations by faculty. For this study, we used pedagogical content knowledge as our conceptual framework.

Of significance for teachers everywhere, this study demonstrated that the understanding and skills of clinician-teachers who teach consistently at the bedside progressed rapidly in a variety of areas related to giving feedback. These included development of knowledge about learners themselves related to normal and abnormal trajectories of learning, development of teaching approaches and strategies, and transitioning to a long-term, developmental approach to working with students rather than remaining focused on immediate, limited, short-term goals and giving general, non-specific feedback.

In alignment with developing skills as a physician in working with a variety of patients and diseases, it appears that clinician-teachers develop a repertoire of "teaching scripts," similar to pattern recognition of patient cases and diseases. ${ }^{17}$ Irby described teaching scripts as analogous to scripts that dictate the action on stage and containing general goals of instruction, key teaching points, specific representations of content (explanations, analogies, examples, learning tasks), an understanding of the conceptions and misconceptions of learners, and procedures for overcoming learning difficulties. He observed that the essence of content-specific instruction is content knowledge organized for teaching purposes that is most comprehensible to particular learners and this is what distinguishes teachers from mere content experts. Marcdante and Simpson described teaching scripts as internalized scripts that contain detailed information about the learner, the goals of a session, specific teaching points for given topics, and effective educational strategies keyed to different learner levels. ${ }^{24}$ These "teaching scripts" may fulfill several roles: providing a repertoire of teaching plans but also permitting teachers to draw upon memory and experience to define learners and their developmental trajectory as well as unique and unusual learner situations. As one "novice" teacher who participated in a focus group in this study said during the focus group session, "I had two students who struggled this year and I'm grateful-now I have two major diagnoses. I can identify those problems in the future."16 
The study also illuminates the complexity inherent in learning to teach. Many teachers begin teaching with content expertise alone; pedagogical understanding is rare. ${ }^{25}$ Our study suggests that a combination of learning and refining interrelated skills is important for mastering teaching in the clinical setting; while content knowledge is an essential ingredient, content alone is insufficient. Faculty development, too, provides valuable tools, examples and practice but by itself likely has limited impact compared with sustained, longitudinal teaching experience. Guided bedside teachers in this study received ongoing monthly sessions with their colleagues in which reflection on different aspects of their teaching routinely occurred. Since other clinicians not working as guided bedside teachers were not also at these sessions, it is impossible to determine with existing data whether the greatest impact was from sustained longitudinal teaching or from the faculty development that these monthly sessions provided. Also important was the opportunity to understand the developmental trajectory of learners, ultimately resulting in the identification of "teaching scripts." In isolated, sporadic teaching sessions where a clinician's time is divided between teaching and clinical care, the ability to pay sustained attention to the learner him/herself is likely limited and therefore limiting.

These two studies of the impact of guided bedside teaching on teachers themselves demonstrate the value for teachers of being placed in longitudinal teaching settings in which time is devoted to teaching and unimpeded by clinical responsibilities. Many clinical teachers teach only sporadically_-sometimes while "on service" or fulfilling attending physician roles for limited periods of time, other times on an occasional basis and frequently in combination with their clinical responsibilities. The guided bedside teaching model is defined by a sustained teaching role with no active clinical responsibilities being undertaken while teaching (although teachers did remain active clinicians when not teaching students). In their teaching skills, teachers were able to progress rapidly, developing a combination of skills as defined by content pedagogical knowledge. In their clinical skills, they perceived themselves as becoming better clinicians and enjoyed their clinical work in a new way. With the contemporary focus on faculty development as the primary avenue to learning and improving teaching skills, this study illuminates the developmental trajectory that being given a concentrated opportunity to teach at the bedside provides for teachers themselves in 
developing skills, comfort, confidence and enjoyment in the process of teaching and in clinical care itself.

\section{Implications for practice}

The Colleges program at the University of Washington, with the advent of a new curriculum in 2015, has subsequently added an outpatient component to preclinical students' clinical training prior to clerkships. Students now experience a combination of guided bedside teaching, twice-monthly clinical skills laboratories and a 12-month outpatient workforce experience in a primary care physician's office - all occurring simultaneously and in tandem. Through the outpatient experience, they at least observe more advanced clinical skills and in many cases practice those skills themselves as their own skills advance. It will be important to test in the future whether students perceive themselves to be better prepared for clerkships in advanced clinical skills with these additions to the program compared with the guided bedside teaching program alone.

\section{Limitations}

Guided bedside teaching as utilized at the University of Washington applies only to inpatient teaching. In an era of increasing focus on ambulatory medicine, students may receive exposure to a patient population that they are less likely to work with during their careers. The advantage, however, of using an inpatient population to train students in fundamental clinical skills is that the students are not learning the art of diagnosis and treating at this stage of training but rather are focusing on the basics of doing a history and physical examination and performing an oral case presentation; these can be performed on virtually any patient independent of setting and diagnosis. Patients in a hospital setting are a "captive audience"; so long as they give their permission to see students, they often have unlimited time for histories and physical examinations. The alternate venues for such training are either with standardized patients, on each other or in outpatient settings. Working with standardized patients and practicing on peers do not provide the diversity or real experiences of patients but rather are a controlled and limited set of experiences. Our students also receive basic training with standardized patients and on each other but the crux of their clinical skills 
training has been with inpatients. We posit that the best possible range of training opportunities would include outpatient settings and, in fact, our school has moved to a model in the past year in which students learn clinical skills through combined settings.

All of the studies in this set of studies involved self-perception. Students and teachers themselves were the source of the perceptions. As such, we do not have objective methods of documentation. However, in analyzing the roles and functions of guided bedside teaching, we feel that these are the appropriate sources and should be taken with full seriousness.

Finally, guided bedside teaching is used in relatively few medical school settings in the United States or internationally. Most medical schools utilize more limited teaching venues for clinical skills. Recently, however, there has been an increased focus in the United States on the use of learning communities in medical education; one mode of learning communities involves guided bedside teaching. Johns Hopkins University and the University of Arizona are two other medical schools that use guided bedside teaching to train their students in clinical skills and the number of schools utilizing learning communities for teaching clinical skills is increasing. ${ }^{4}$ We feel that our studies provide data that will encourage increased use of guided bedside teaching in more medical school settings.

\section{Conclusions}

This study illuminates the roles and functions of guided bedside teachers for students and for teachers themselves. It adds to the existing literature on the impact of guided bedside teaching on student preparation for clerkships, as evidenced by improved performance ${ }^{7}$ and greater self-confidence, ${ }^{8}$ by demonstrating the unique roles, functions and advantages of guided bedside teaching in advancing students' and teachers' clinical skills. It highlights an area in which medical education has expended relatively limited attention. Yet development of best approaches to introducing medical students to clinical skills could not be more important. Our studies argue for a dedicated approach to training preclinical students in the development of clinical skills that involves students being placed in small groups with a faculty mentor on a sustained basis and receiving direct experience with real patients using a curriculum that encourages progressive skill development. The rewards are not just to students; teachers 
themselves benefit from this approach through improved clinical skills and rapid progression in their teaching skills. We believe that guided bedside teaching can be most effective when separated from the teachers' own clinical responsibilities in order to maximize their attention to students and to teaching. 


\section{REFERENCES}

1. Dornan T, Boshuizen HP, King N, Scherpbier A. Experience-based learning: A model linking the processes and outcomes of medical students' workplace learning. Med Educ 2007;41:84-91.

2. Prince KJAH, Boshuizen HPA, van der Vleuten CPM, Scherpbier AJJA. Students' opinions about their preparation for clinical practice. Med Educ 2005;39:704-712.

3. Windish DM, Paulman PM, Goroll AH, Bass EB. Do clerkship directors think medical students are prepared for the clerkship years? Acad Med 2004 Jan;79(1):56-61.

4. Smith S, Shochet R, Keeley M, Fleming A, Moynahan K. The growth of learning communities in undergraduate medical education. Acad Med 2014 Jun;89(6):928-33.

5. Shochet R. Learning communities: A new twist to medical education. Md Med 2012;13:13-4.

6. Ferguson KJ, Wolter EM, Yarbrough DB, Carline JD, Krupat E. Defining and describing learning communities: results of a national survey. Acad Med 2009 Nov;84(11):154956.

7. Jackson MB Keen M, Wenrich MD, Schaad DC, Robins L, Goldstein EA. Impact of a pre-clinical clinical skills curriculum on student performance in third-year clerkships. Arch Int Med 2009;24:929-933.

8. Whipple ME, Barlow CB, Smith S, Goldstein EA. Early introduction of clinical skills improves medical student comfort at the start of clerkships. Acad Med 2006; 81 (10 Suppl): 540-543.

9. Wenrich M, Jackson MB, Scherpbier AJ, Wolfhagen IH, Ramsey PG, Goldstein EA. Ready or not? Expectations of faculty and medical students for clinical skills preparation for clerkships. Med Ed Online 2010; 15: 52005.

10. Wenrich MD, Jackson MB, Wolfhagen I, Ramsey PG, Scherpbier AJJ. What are the benefits of early patient contact? A comparison of three preclinical patient contact settings. BMC Med Ed 2013; 13:80.

11. Howe A Dagley V, Hopayian K, Lillicrap M. Patient contact in the first year of basic medical training_feasible, educational acceptable? Med Teach 2007 ;29(2-3):237-45. 
12. Dornan T, Littlewood S, Margolis SA, Scherpbier A, Spencer J, Ypinazar V. How can experience in clinical and community settings contribute to early medical education? A BEME systematic review. Med Teach 2006;28:3-18.

13. Khan I, Fareed A., Perceptions of students and faculty about conventional learning and community-oriented medical education. Coll Physicians Surg Pak 2003; ;13:82-5.

14. MacLleod RD, Parkin C, Pullon S, Robertson G. Early clinical exposure to people who are dying. Med Educ 2003; 37:51-58.

15. Wenrich MD, Jackson MB, Ajam KS, Wolfhagen IH, Ramsey PG, Scherpbier AJ. Teachers as learners: the effect of bedside teaching on the clinical skills of clinicianteachers. Acad Med 2011;86:846-52.

16. Wenrich MD, Jackson MB, Maestas RM, Wolfhagen IHAP, Scherpbier AJJ. From cheerleader to coach: the developmental progression of bedside teachers in giving feedback to early learners. Acad Med 2015; 90:591-597.

17. Irby DM. Irby DM. Excellence in clinical teaching: knowledge transformation and development required. Med Educ 2014;48:776-84.

18. Sutkin G, Wagner E, Harris I, Schiffer R. What makes a good clinical teacher in medicine: A review of the literature. Acad Med 2008; 83:452-466.

19. Irby DM. Clinical teacher effectiveness in medicine. J Med Educ 1978;53:808-815.

20. Irby DM. Three exemplary models of case-based teaching. Acad Med 1994;69:333-342.

21. Pinsky LE, Monson D, Irby DM. How excellent teachers are made: Reflecting on success to improve teaching. Adv Health Sci Educ Theory Prac 1998;3:207-215.

22. Wagner JM, Fleming AE, Moynahan KF, Keeley MG, Bernstein IH, Shochet RB. Benefits to faculty involved in medical school learning communities. Med Teach 2015;37:476-81.

23. Irby DM. What clinical teachers in medicine need to know. Acad Med 1994;69:3333342.

24. Marcdante KW, Simpson D. How pediatric educators know what to teach: the use of teaching scripts. Pediatrics 1999; 104:148-150.

25. Cantillon P, Grave W. Conceptualising GP teachers' knowledge: a pedagogical content knowledge perspective. Educ Prim Care 2012;23:178-185. 


\section{CHAPTER 7}

SUMMARY 
The goal of this thesis was to shed light on what are the benefits, limitations and outcomes associated with the educational approach of "guided bedside teaching" for preclinical medical students and the faculty who teach them. Earlier studies elucidated the positive impact of guided bedside teaching on student comfort with clerkships and student success in clerkships. We aimed to build on this knowledge about outcomes in a two-fold approach. Our first aim was to understand whether and how guided bedside teaching prepares students for clerkships and to evaluate the comparative benefits and limitations of guided bedside teaching from the perspectives of medical students. The second was to understand how guided bedside teaching impacts the teachers themselves who participate in guided bedside teaching in terms of their own development as clinicians and as teachers.

In Chapter 1, we present the relevant literature as it relates to the topics in this thesis, define the history and development of guided bedside teaching as an approach and what gaps it fills, and outline the research questions. Two of the research questions relate to how guided bedside teaching impacts preclinical medical students in their progression of learning clinical skills and the other two research questions relate to how guided bedside teaching impacts the teachers themselves as clinicians and as their teaching moves from novice to master status.

Chapter 2: Key transition points during medical school are the transition from the preclinical basic science curriculum to clerkships and the transition from clerkships to graduate medical education. An integrated, developmental curriculum will have alignment in goals and expectations across these periods of training. Guided bedside teaching prepares students for the transition from the preclinical curriculum to the clinical curriculum by teaching them the basic clinical skills needed in clerkship. But true integration will demonstrate alignment in the goals and expectations of each key group involved - in this case, medical students as they make the transition, guided bedside teachers who have trained them, and clerkship directors who assume their training in the next phase. In this study, we asked, what clinical skills are needed for clerkships? We addressed the question from the perspectives of these three key groups: medical students shortly after starting clerkships, faculty serving as guided bedside teachers of preclinical students, and clerkship directors involved in leading clinical clerkships. Alignment of expectations would suggest the potential for successful student preparation for clerkships. The paper found differing expectations from the three groups, with 
the highest expectations coming from medical students themselves and the lowest expectations from clerkship directors. Students had high expectations not only for the acquisition of basic clinical skills but also for more advanced skills like preparing an assessment and plan and differential diagnosis. The study suggested the need for greater communication about and integration of expectations for goals and objectives in clinical skills training in order to maximize student success in clerkships and to maximize the impact of guided bedside teaching for both learners and teachers. However, the study suggests relatively strong congruence between the expectations of guided bedside teachers and clerkship directors, which is a positive indication that guided bedside teaching and clerkship teaching are moving along a developmental trajectory.

Chapter 3: Guided bedside teaching is only one method for providing preclinical exposure to patients prior to clerkships. Other approaches are the more commonly used preceptorships. In the study described in Chapter 3, we posed the question of whether and in what ways guided bedside teaching differs from more commonly used approaches and what unique advantages, if any, it offers to students. The study used the perspectives of students themselves who complete three different types of preclinical training with patients and found that guided bedside teaching offers more systematic and comprehensive training in clinical skills. In comparison, preceptorships offer a realistic and more practical introduction to what clinical medicine looks like in the real world and the world awaiting students in the future. Both therefore offer unique advantages and complement one another in terms of what they offer students.

Chapter 4: In order for guided bedside teaching to succeed as a teaching approach, it must offer benefits to both students and faculty. In Chapter 4, we utilized a series of interviews completed over the first five years of the guided bedside teaching program at our institution to isolate one theme area identified as important to these teachers: the acquisition and improvement of clinical skills as a direct consequence of serving as guided bedside teachers. Through a qualitative analysis, this paper examined how faculty perceive that sustained bedside teaching with preclinical medical students impacts their own clinical skills. Six themes were associated with the influence of bedside teaching on teachers' skills and practices. One related to deterrents to change that narrowed teachers' practice skills prior to 
starting bedside teaching. Three related to expansion of the process of clinical care resulting from bedside teaching: expanded knowledge and skills, deconstructing the clinical experience, and greater self-reflection. Two were perceived outcomes: improved clinical skills (e.g., physical examination) and more mindful practices (e.g., self-confidence, patientcentered). These findings suggest a strong positive influence of serving as guided bedside teachers on their own skills as clinicians.

Chapter 5: While many papers have presented research and/or opinions on what defines a good clinical teacher, few provide insight into the progression of teachers from novices to more experienced teachers. Such information, if available, could help to build faculty development approaches and programs. Interviews from faculty over the first five years of a teaching program provide the opportunity to delve into a question for which there is little existing information: in what specific areas do teachers progress in their teaching skills as they learn to become teachers? In the study described in Chapter 5, we isolated one skill theme from the year-long qualitative analysis of College faculty interviews described above for detailed examination: giving feedback to students. We asked the question: how do clinical teachers progress in their skills and approaches to giving feedback to students at the bedside over time based on their experience working with students? Themes related to giving feedback demonstrated a dyadic structure: characteristic of less experienced teachers versus characteristic of experienced teachers. Seven dominant dyadic themes emerged, including teacher as cheerleader versus coach, concern about student fragility versus understanding resilience, and focus on creating a safe environment versus challenging students within a safe environment. This study demonstrated that with consistent teaching, clinical teachers demonstrated progress in giving feedback to students in multiple areas, including understanding students' developmental trajectory and needs, developing tools and strategies, and adopting a dynamic, challenging, inclusive team approach. Ongoing teaching opportunities with targeted faculty development may help improve clinician-teachers' feedback skills and approaches.

Chapter 6: The results of the studies described in chapter 2-5 are discussed in relation to the relevant literature. Perspectives on future research are set out. 
SAMENVATTING IN NEDERLANDS 
Dit proefschrift beoogde in kaart te brengen wat de voordelen, beperkingen en resultaten zijn van de onderwijsmethode "begeleid bedside-teaching", ofwel begeleid onderwijs aan het ziekbed, voor geneeskundestudenten in de preklinische fase en voor de docenten die hen onderwijzen. Voorgaande studies hebben het positieve effect belicht van begeleid bedsideteaching op de tevredenheid van studenten met de coschappen en hun succes tijdens de coschappen. Ons doel was om op deze kennis over resultaten voort te bouwen door middel van een tweeledige aanpak. Ons eerste doel was om te begrijpen of en hoe begeleid bedsideteaching studenten voorbereidt op de coschappen en te onderzoeken wat volgens geneeskundestudenten de relatieve voordelen en beperkingen zijn van begeleid bedsideteaching. Het tweede doel was om te begrijpen hoe begeleid bedside-teaching de docenten die aan bedside-teaching deelnemen zelf beïnvloedt wat betreft hun eigen ontwikkeling als clinici en als onderwijzers.

In Hoofdstuk 1 geven we een overzicht van de relevante literatuur en laten we zien hoe deze bij de onderwerpen in dit proefschrift aansluit, om de geschiedenis en ontwikkeling van begeleid bedside-teaching als onderwijsmethode vast te stellen en aan te tonen welke hiaten het opvult, en om de onderzoeksvragen uiteen te zetten. Twee van de onderzoeksvragen hebben betrekking op de vraag welke invloed begeleid bedside-teaching heeft op het aanleren van klinische vaardigheden door geneeskundestudenten tijdens de preklinische fase en de andere twee onderzoeksvragen hebben betrekking op de vraag hoe begeleid bedside-teaching de docenten zelf beïnvloedt als clinici en

onderwijl zij groeien in hun docentenrol van nieuweling naar meester.Hoofdstuk 2: Belangrijke overgangsmomenten tijdens de geneeskundeopleiding zijn de overgang van het preklinische basiswetenschappencurriculum naar de coschappen en de overgang van de coschappen naar de vervolgopleiding. Een geïntegreerd, ontwikkelingsgericht curriculum vraagt om een goede afstemming tussen de doelstellingen en eisen van elk van deze opleidingsfases. Begeleid bedside-teaching bereidt studenten voor op de overgang van het preklinische curriculum naar het klinische curriculum door hun de klinische basisvaardigheden aan te leren die voor de coschappen vereist zijn. Maar echte integratie vraagt ook om afstemming tussen de doelstellingen en eisen van elk van de betrokken kerngroepen, in dit geval de geneeskundestudenten die de overgang maken, de docenten die 
hen hebben begeleid tijdens het bedside-teaching en de coschapcoördinatoren die verantwoordelijk zijn voor hun opleiding in de vervolgfase. In deze studie stelden we de vraag: welke klinische vaardigheden zijn er nodig voor de coschappen? We stelden deze vraag vanuit het perspectief van de drie betreffende kerngroepen: geneeskundestudenten die pas aan de coschappen begonnen waren, docenten gemoeid met het verzorgen van begeleid bedside-teaching voor studenten in de preklinische fase, en coschapcoördinatoren betrokken bij het beheer van klinische coschappen. Daarbij veronderstelden we dat een goede afstemming van eisen betekende dat de kans dat studenten succesvol op de coschappen worden voorbereid aanwezig is. De bevinding van het artikel was dat de drie groepen verschillende eisen stelden; daarbij stelden de geneeskundestudenten zelf de hoogste eisen en de coschapcoördinatoren de laagste. Studenten stelden niet alleen hoge eisen aan het aanleren van klinische basisvaardigheden, maar ook aan de ontwikkeling van meer gevorderde vaardigheden, zoals het maken van een beoordeling en formuleren van behandelbeleid en differentiële diagnose. De studie gaf aan dat er meer gecommuniceerd moet worden over de eisen voor doelstellingen en eindtermen van het klinisch vaardigheidsonderwijs en dat deze beter op elkaar moeten worden afgestemd om er voor te zorgen dat studenten de coschappen zo succesvol mogelijk doorlopen en dat zowel studenten als docenten zoveel mogelijk voordeel behalen uit begeleid bedside-teaching. De studie gaf echter ook aan dat de eisen van docenten van bedside-teaching en van coschapcoördinatoren betrekkelijk veel met elkaar overeenstemden, wat wijst op het positieve gegeven dat begeleid bedside-teaching en het coschaponderwijs zich in dezelfde richting ontwikkelen.

Hoofdstuk 3: Begeleid bedside-teaching is slechts één methode die contact met patiënten in de preklinische fase, vóór de coschappen, mogelijk maakt. Andere methodes zijn de vaker toegepaste zogenaamde "preceptorships"*. In de in Hoofdstuk 3 beschreven studie stelden we de vraag of en, zo ja, op welke manier begeleid bedside-teaching verschilt van de meer gebruikelijke methodes en wat de eventuele unieke voordelen ervan zijn voor studenten. De studie maakte gebruik van de meningen van studenten zelf die drie verschillende vormen van preklinische training met patiënten doorliepen en concludeerde dat er bij begeleid bedsideteaching sprake is van een systematischere en bredere training van klinische vaardigheden. Preceptorships daarentegen bieden een realistische en praktischere inleiding op hoe de klinische geneeskunde er uitziet in de echte wereld en in de wereld die studenten later te 
wachten staat. Beide methoden bieden dus unieke voordelen en vullen elkaar aan wat betreft hetgeen zij studenten kunnen bieden.

Hoofdstuk 4: Begeleid bedside-teaching is pas een succesvolle onderwijsmethode wanneer het voordelen heeft voor zowel studenten als docenten. In Hoofdstuk 4 maakten we gebruik van een reeks interviews die tijdens de eerste vijf jaar van het begeleid bedsideteachingprogramma aan onze instelling waren afgenomen en destilleerden daaruit één themagebied dat als belangrijk voor deze docenten werd aangemerkt, namelijk: de verwerving en verbetering van klinische vaardigheden als direct gevolg van het begeleid bedside-teachingdocentschap. Dit artikel onderzocht met behulp van een kwalitatieve analyse hoe, in de beleving van docenten, structurele deelname aan bedside-teaching met preklinische geneeskundestudenten hun eigen klinische vaardigheden beïnvloedde. Zes thema's hielden verband met de invloed van bedside-teaching op de vaardigheden en beroepsuitoefening van docenten. Een had te maken met belemmeringen die verandering tegenhielden waardoor docenten beperkte praktijkvaardigheden hadden voordat zij met bedside-teaching begonnen. Drie hadden betrekking op een verruiming van het klinische zorgproces als gevolg van bedside-teaching: meer kennis en vaardigheden, deconstructie van de klinische ervaring en meer zelfreflectie. Twee waren waargenomen resultaten: verbeterde klinische vaardigheden (bijv. lichamelijk onderzoek) en meer bedachtzaam handelen (bijv. zelfvertrouwen, patiëntgericht). Deze bevindingen duiden op een sterke positieve invloed van het begeleid bedside-teachingdocentschap op de eigen vaardigheden als clinici.

Hoofdstuk 5: Hoewel veel artikelen onderzoek en/of meningen hebben gepresenteerd over wat een goede klinisch docent nu precies kenmerkt, zijn er weinig die inzicht bieden in de ontwikkeling van docenten van nieuweling tot meer ervaren docent. Dergelijke informatie, indien beschikbaar, zou ten goede kunnen komen aan de ontwikkeling van docentprofessionaliseringsstrategieën en -programma's. Interviews met docenten gedurende de eerste vijf jaar van een onderwijsprogramma boden de kans om ons te verdiepen in een vraag waarvoor er tot dusver weinig informatie voorhanden was: op welke specifieke vlakken verbeteren docenten hun doceervaardigheden naarmate zij zich ontplooien tot volwaardig docent? In de in Hoofdstuk 5 beschreven studie selecteerden we één van de hiervoor besproken vaardigheidsthema's die voortkwamen uit de één jaar durende kwalitatieve 
analyse van interviews met docenten aan een universiteit voor nader onderzoek: het geven van feedback aan studenten. We stelden de vraag: hoe verbeteren klinisch docenten hun vaardigheid in het geven van feedback aan studenten aan het ziekbed en hun aanpak daartoe naarmate zij steeds meer ervaring opbouwen in het werken met studenten? De thema's die verband hielden met het geven van feedback waren tweeledig: kenmerkend voor minder ervaren docenten tegenover kenmerkend voor ervaren docenten. Er kwamen zeven dominante tweeledige thema's bovendrijven, waaronder "de docent als aanmoediger tegenover coach", "bezorgdheid over de kwetsbaarheid van de student tegenover het begrijpen van veerkracht" en "gericht zijn op het creëren van een veilige omgeving tegenover het uitdagen van de student binnen een veilige omgeving". Deze studie toonde aan dat docenten door structureel les te geven op diverse vlakken groeiden in het geven van feedback aan studenten, zoals het begrijpen van het ontwikkelingstraject en de behoeften van studenten, het bedenken van handvatten en strategieën en het hanteren van een dynamische, uitdagende, inclusieve teambenadering. Structurele onderwijskansen in combinatie met gerichte docentprofessionalisering kan bijdragen aan een verbetering van de feedbackvaardigheden en -aanpak van klinisch docenten.

Hoofdstuk 6: De bevindingen van de in Hoofdstuk $2 \mathrm{t} / \mathrm{m} 5$ beschreven studies worden besproken in het licht van de betreffende literatuur. Daarbij worden mogelijke uitgangspunten voor toekomstig onderzoek uiteengezet. 



\section{ACKNOWLEDGEMENTS}

I thank my family for their support during my meandering academic odyssey throughout these many years. I also thank my colleagues - in particular Paul Ramsey, dean of the University of Washington School of Medicine, who is responsible for my initial interest and ongoing involvement in health services and health professions research and who has been highly supportive throughout my career. I have had the pleasure of working for nearly 40 years at one of the best medical schools in the world and it has been a privilege to work alongside so many talented, dedicated individuals. Molly Blackley Jackson was a wonderful collaborator in all of the studies presented in this book. Thank you as well to my dissertation supervisors: in addition to Dr. Ramsey, Albert Scherpbier and Ineke Wolfhagen. All of these individuals have added immeasurably to my knowledge and ability to think critically and joyfully about the world of medical education. 


\section{ABOUT THE AUTHOR}

Marjorie Wenrich was born on December 19, 1949 in Berkeley, California. After obtaining her bachelor's degree from Antioch College in Ohio in 1973, Ms. Wenrich worked for several years in different positions, including in health services research. In 1980, after a move from California to Washington, she began working at the University of Washington (UW) School of Medicine as Student Coordinator in the Department of Medicine. After several years in this position, Dr. Paul Ramsey offered her a position coordinating a research project funded by the American Board of Internal Medicine (ABIM) to study the predictive validity of specialty board certification. Working on this study led to Ms. Wenrich's deep interest in the areas of physician competence and methods to assess physician performance. The study, published in 1989, was considered a landmark study in predictive validity and also led to new recertification initiatives at the ABIM. It also resulted in a second ABIM-funded study that examined physician performance broadly, including physicians' communication skills. This study resulted in the development, testing and use of peer ratings by the ABIM for board recertification. Subsequent studies Ms. Wenrich was involved in examined physician competence at identifying and managing HIV infection and physicians' skills in giving bad news to patients with life-threatening illness. Ms. Wenrich received a Master's in Public Health at the University of Washington in 1994. Her career in developing methods to assess physician competence and related area continued for a number of years. In 1999, she transitioned from the Department of Medicine to the School of Medicine and became increasingly involved in medical education at the undergraduate level. She followed closely the Colleges program as it was developed and subsequently made this groundbreaking program the center of her dissertation at Maastricht University. In 2016, she became associate dean for education strategies at the UW School of Medicine. With her colleague Michael Ryan, she co-led the implementation of a major curriculum reform for the medical school, which spans five states and nearly one-quarter of the American landmass. She is an author on 55 publications; 12 as first author. 


\section{SHE Dissertations Series}

The SHE Dissertation Series publishes dissertations of $\mathrm{PhD}$ candidates from the School of Health Professions Education (SHE) who defended their PhD theses at Maastricht University. The most recent ones are listed below. For more information go to: https://she.mumc.maastrichtuniversity.nl

Waterval, D. (26-04-2018) Copy but not paste, an exploration of crossborder medical curriculum partnerships

Smirnova, A. (04-04-2018) Unpacking quality in residency training and health care delivery

Hikspoor, J. (05-12-2017) Development of the heart and vessels in the caudal part of the human body

Boymans, T. (06-10-2017) Hip arthroplasty in the very elderly: anatomical and clinical considerations

Zaidi, Z. (04-10-2017) Cultural hegemony in medical education: exploring the visibility of culture in health professions

Harrison, C. (20-09-2017) Feedback in the context of high-stakes assessment: can summative be formative?

Mekonen, H. (30-06-2017) Development of the axial musculo-skeletal system in humans

Taylor, T. (29-03-2017) Exploring Fatigue as a Social Construct: Implications for Work Hour Reform in Postgraduate Medical Education

McLellan, L. (29-03-2017) Prescribing the right medicine: Perspectives on education and practice

Ignacio, J. (09-02-2017) Stress Management in Crisis Event Simulations for Enhancing Performance

Bolink, S. (19-01-2017) Functional outcome assessment following total hip and knee arthroplasty; Implementing wearable motion sensors

Beckers, J. (09-12-2016) With a little help from my e-portfolio. Supporting students' selfdirected learning in senior vocational education

Giroldi, E. (07-12-2016) Towards skilled doctor-patient communication. Putting goaldirected and context-specific communication into (educational) practice

Huwendiek, S. (25-11-2016) Virtual patients for learning of clinical reasoning 
Bohle-Carbonell, K. (28-09-2016) May I ask you...? The influence of individual, dyadic \& network factors on the emergence of information exchange in teams

Ginsburg, S. (01-09-2016) Hidden in plain sight, the untapped potential of written assessment comments

Koops, W. (08-06-2016) Computer-supported collaborative learning in clinical clerkships

Schlegel, C. (08-06-2016) Simulated and standardized patients in health profession education: the impact of quality improvement

Sorensen, J. 01-06-2016 Obstetric simulation: designing simulation-based medical education and the role of physical fidelity

Kok, E. (01-04-2016 Developing visual expertise: from shades of grey to diagnostic reasoning in radiology 